\title{
Telomerase Inhibitors from Natural Products and Their Anticancer Potential
}

\author{
Kumar Ganesan (iD) and Baojun $\mathrm{Xu}$ * \\ Food Science and Technology Program, Beijing Normal University-Hong Kong Baptist University United \\ International College, Zhuhai 519087, China; kumarganesan@uic.edu.hk \\ * Correspondence: baojunxu@uic.edu.hk; Tel.: +86-756-3620-636; Fax: +86-756-3620-882
}

Received: 23 November 2017; Accepted: 19 December 2017; Published: 21 December 2017

\begin{abstract}
Telomeres and telomerase are nowadays exploring traits on targets for anticancer therapy. Telomerase is a unique reverse transcriptase enzyme, considered as a primary factor in almost all cancer cells, which is mainly responsible to regulate the telomere length. Hence, telomerase ensures the indefinite cell proliferation during malignancy-a hallmark of cancer-and this distinctive feature has provided telomerase as the preferred target for drug development in cancer therapy. Deactivation of telomerase and telomere destabilization by natural products provides an opening to succeed new targets for cancer therapy. This review aims to provide a fundamental knowledge for research on telomere, working regulation of telomerase and its various binding proteins to inhibit the telomere/telomerase complex. In addition, the review summarizes the inhibitors of the enzyme catalytic subunit and RNA component, natural products that target telomeres, and suppression of transcriptional and post-transcriptional levels. This extensive understanding of telomerase biology will provide indispensable information for enhancing the efficiency of rational anti-cancer drug design.
\end{abstract}

Keywords: telomere; telomerase inhibitors; natural products; anticancer

\section{Introduction}

Telomerase was initially investigated in the transformed cervical carcinoma (HeLa) cell line in 1989 [1]. In eukaryotes, terminal bases of a linear DNA molecule cannot replicate by normal DNA polymerases and primases. Due to the lacking mechanisms, in each round of DNA replication, chromosomes will shorten with the abolishing of terminal RNA primers [2,3]. Telomerase is a ribonucleic reverse transcriptase enzyme, which reimburses for the loss of those telomeric sequences by connecting tandem repeats at the $3^{\prime}$ end of chromosomes, which produce the telomeres. This enzyme adds nucleotide repeats to telomeres by using RNA template providing karyotype stability and compensating for the loss of DNA replication [4]. However, in normal human somatic cells, this enzyme shows little or no telomerase activity. The telomeric DNA is eventually shortened with each cell division [5]. Telomeres are regions of non-coding DNA constrained at the end of each chromosome whose length indicates life expectancy and overall health status. Based on the structural and functional aspects, telomeres are unique and district from other chromosomal DNA. Telomeres are sequenced by short pattern tandem repetitions of hexanucleotide (TTAGGG) in all eukaryotic organisms. They are essential components that stabilize the ends of eukaryotic chromosome and avoid the loss of genetic information [6]. Telomeres normally defend the chromosome from DNA damage and exonucleolytic degradation, and prevent aberrant recombination and chromosome-to-chromosome fusion. The average lengths of telomeres vary from species to species. Telomeres normally help to control the proliferative capacity of normal somatic cells [7].

Eukaryotic telomerase contains a catalytic protein subunit known as telomerase reverse transcriptase component (hTERT), which is conserved by reverse transcriptase (RT) enzymes. 
In addition, telomerase contains an integral RNA component (hTR), which is essential for the synthesis of the telomeric repeats [8]. Telomerase is predominantly expressed in human tumors and tumor-derived cell lines, about $85-90 \%$. However, in the normal stem cell, this enzyme activity is proportionally low [9]. The function of telomerase is mainly involved in telomere capping and responding to DNA-damage [10]. Telomere length is maintained in human tumors by many factors other than telomerase activity. Normally, the level of telomerase activity is high in tumor cells; in addition, telomere length is further regulated by recombinant factors called as alternative lengthening of telomere (ALT) [7]. The absence of telomerase activity in ALT causes chromatin/methylation remodeling of the catalytic proteins, hTERT and hTR [11]. Based on the catalytic activities and recombination factors, the telomere is highly heterogeneous in length in cancer cells. Based on the telomere maintenance, unlimited cell proliferation occurs in cancer [12]. Telomerase could be a reliable marker and potential target for some important cancers; however, it does not play a role in all cancers or immortal cell growth inhibitors [13]. Only 15\% of cancers enable its telomere by ALT. Besides that, the development of telomerase inhibitors as anti-cancer agents is reasonable and feasible. Hence, most telomere-related antitumor strategies target telomere maintenance through the telomerase-dependent mechanism. Numerous telomerase inhibitors have been produced and inhibit the catalytic activity of enzyme through the targeting of its catalytic components or RNA. Telomerase inhibitors are generally diverse compounds, including natural as well as synthetic products and modified oligonucleotides [7]. Telomere binding agents such as quadruplex ligands (G4) can play a role in both telomerase positive and ALT cells. However, based on the available literature, there is no inhibitor specifically for the ALT mechanism.

Telomerase is generally observed in most cancer cells and is critical for cancer cell development [14]. Hence, the deactivation or inhibition of telomerase is essential in the cancer-suppressive mechanism. The deactivation of telomerase and destabilization of telomere by natural/synthetic products provides extensive opportunity to succeed new targets for cancer therapy. Nowadays, several synthetic compounds are commercially used for chemotherapy of cancer. However, most have many side-effects or complications in the cancer patients. Hence, it is very important to explore the beneficial effects of natural products such as medicinal plants on the various cancer cells and potential anti-cancer therapeutic effects [15]. Moreover, natural products are normally taken in the human diet as the traditional medicine that are edible, safe to consume and have higher acceptability among the individuals [16]. Besides that, natural products reduce/inhibit the telomerase activity that can be utilized as functional food by the cancer individual for healing or treatment. Thus, this review puts forward the use of natural products that inhibit the telomerase as a phytomedicine in cancer prevention, which can be noted as a direction for future research on targets for cancer therapy (Figure 1). Furthermore, this review aims to provide fundamental knowledge for research on the telomerase structure, functions, working regulation of telomerase and its various binding proteins to inhibit the telomere/telomerase complex. In addition, the review summarizes the inhibitors of the enzyme catalytic subunit and RNA component, natural products that target telomeres and suppression of transcriptional and post-transcriptional levels.

Telomeres are normally located at a terminal of the chromosomes of all organisms, comprising DNA. The repetitive sequences of telomeric DNA rich in guanine with a single-stranded $3^{\prime}$ end, which folds onto the double-stranded telomere and, eventually, becomes a t-loop structure. This t-loop structure causes cap formation at the chromosome ends, which protects from degradation, recombination, and end-to-end fusion. Telomere is generally able to maintain a certain length of the strand through telomerase enzyme and regulatory proteins. Several telomeric proteins, telomerase components and telomere repair proteins are required to maintain certain tasks by binding with single/double-stranded telomeric DNA. Significant double-strand telomere DNA-binding proteins include telomeric repeat binding factor 1 (TRF1) and telomeric repeat binding factor 2 (TRF2), which are responsible for formation of t-loop and telomere complex. Furthermore, telomere is conserved 
through the complex formed by these regulatory special proteins [17-20]. The other telomere proteins that compose this complex and their duties are briefly summarized in Table 1.

Table 1. Telomere and telomerase-associated proteins.

\begin{tabular}{|c|c|c|}
\hline Protein & Functions & References \\
\hline \multicolumn{3}{|c|}{ Telomerase Components } \\
\hline Heat shock 90 kDa protein (Hsp90) & $\begin{array}{l}\text { Hsp90 is a molecular chaperone, involved in the activation of } \\
\text { disparate client proteins }\end{array}$ & [21-23] \\
\hline Human telomerase reverse transcriptase (hTERT) & $\begin{array}{l}\text { Encodes a rate-limiting catalytic subunit of telomerase that } \\
\text { maintains genomic integrity }\end{array}$ & [24-26] \\
\hline Human telomerase RNA component (hTERC) & $\begin{array}{l}\text { Encodes the RNA component of human telomerase that acts } \\
\text { as a template for the addition of the repeat sequence }\end{array}$ & {$[27,28]$} \\
\hline Telomerase-associated protein 1 (TP1) & $\begin{array}{l}\text { Associated with a catalytic subunit in a multicomponent } \\
\text { telomerase complex }\end{array}$ & {$[29,30]$} \\
\hline \multicolumn{3}{|c|}{ Telomere Binding Proteins } \\
\hline Dyskerin, & $\begin{array}{l}\text { Catalyzes pseudouridylation of rRNA required for correct } \\
\text { intranuclear trafficking of TERC, the RNA component of the } \\
\text { TERT enzyme }\end{array}$ & [31] \\
\hline $\begin{array}{l}\text { PINX1 (PIN2/TERF1-interacting telomerase } \\
\text { inhibitor 1) }\end{array}$ & $\begin{array}{l}\text { Potential telomerase inhibitor, negatively regulating telomere } \\
\text { length by interacting with TRF1. }\end{array}$ & {$[32,33]$} \\
\hline Rap 1 (Repressor activator protein 1 ) & Mammalian Rap1, whose function is still unclear, & [34] \\
\hline $\begin{array}{l}\text { TANK1 and TANK2; Tankyrase (TANK) } \\
\text { telomere-associated poly (ADP-ribose) } \\
\text { polymerase (PARP) } 1\end{array}$ & $\begin{array}{l}\text { Positive regulator of telomere length through inhibition } \\
\text { of TRF1 }\end{array}$ & [35] \\
\hline $\begin{array}{l}\text { Tankyrase, TRF1-interacting ankyrin-related poly } \\
\text { (ADP-ribose) polymerase (PARP) }\end{array}$ & $\begin{array}{l}\text { Mediates poly-ADP-ribosylation of TERF1, thereby } \\
\text { contributing to the regulation of telomere length }\end{array}$ & [36] \\
\hline $\begin{array}{l}\text { Telomere-end-binding protein-Protection of } \\
\text { telomeres } 1 \text { (POT1) }\end{array}$ & $\begin{array}{l}\text { Essential for the replication of chromosome termini and } \\
\text { involved in the regulation of telomere length by cis-inhibition } \\
\text { of telomerase }\end{array}$ & [37] \\
\hline Telomeric-repeat-binding factor 1 (TRF1) & Telomere length regulation & [38] \\
\hline TERF1-interacting nuclear factor 2 (TINF2) & Involves in the regulation of telomere length and protection & [39] \\
\hline \multicolumn{3}{|c|}{ Telomere Repairing Proteins } \\
\hline KU70 (Thyroid autoantigen $70 \mathrm{kDa}$ (Ku antigen) & $\begin{array}{l}\text { Acts as a negative regulator of telomerase and required for } \\
\text { maintenance of the telomeric C-rich strand }\end{array}$ & {$[40,41]$} \\
\hline MRE11 (Meiotic recombination 11 homologue) & $\begin{array}{l}\text { A component of the MRN complex, which plays a central role } \\
\text { in double-strand break (DSB) repair, DNA recombination, } \\
\text { maintenance of telomere integrity and meiosis }\end{array}$ & [42] \\
\hline Rad50 (S. cerevisiae) homologue & $\begin{array}{l}\text { Single-strand endonuclease activity and } \\
\text { double-strand-specific } 3^{\prime}-5^{\prime} \text { exonuclease activity, which are } \\
\text { provided by MRE11 }\end{array}$ & [42] \\
\hline Tripeptidyl-peptidase I (TPP1) & $\begin{array}{l}\text { Plays a role in telomere capping by interacting with TIN2 } \\
\text { and POT1 }\end{array}$ & {$[43,44]$} \\
\hline $\begin{array}{l}\text { XRCC5/KU80 (X-ray repair (double-strand-break } \\
\text { rejoining; Ku autoantigen, } 80 \mathrm{kDa} \text { ) }\end{array}$ & $\begin{array}{l}\text { Works in the } 3^{\prime}-5^{\prime} \text { direction and binds to DNA mediated } \\
\text { by XRCC } 6\end{array}$ & [44] \\
\hline H2AX (Histone $2 \mathrm{AX}$ ) & $\begin{array}{l}\text { Requires for checkpoint-mediated arrest of cell cycle } \\
\text { progression in response to low doses of ionizing radiation and } \\
\text { for efficient repair of DNA double-strand breaks }\end{array}$ & {$[45,46]$} \\
\hline Ku86 (Ku autoantigen, 80 kDa) & $\begin{array}{l}\text { Negative regulator of telomere length, role in telomere } \\
\text { capping, regulation of telomerase recruitment }\end{array}$ & [47] \\
\hline DNA-PK (DNA-dependent protein kinase) & $\begin{array}{l}\text { Plays a role in telomere capping, putative role in } \\
\text { post-replicative processing of telomeres }\end{array}$ & {$[41,48]$} \\
\hline
\end{tabular}




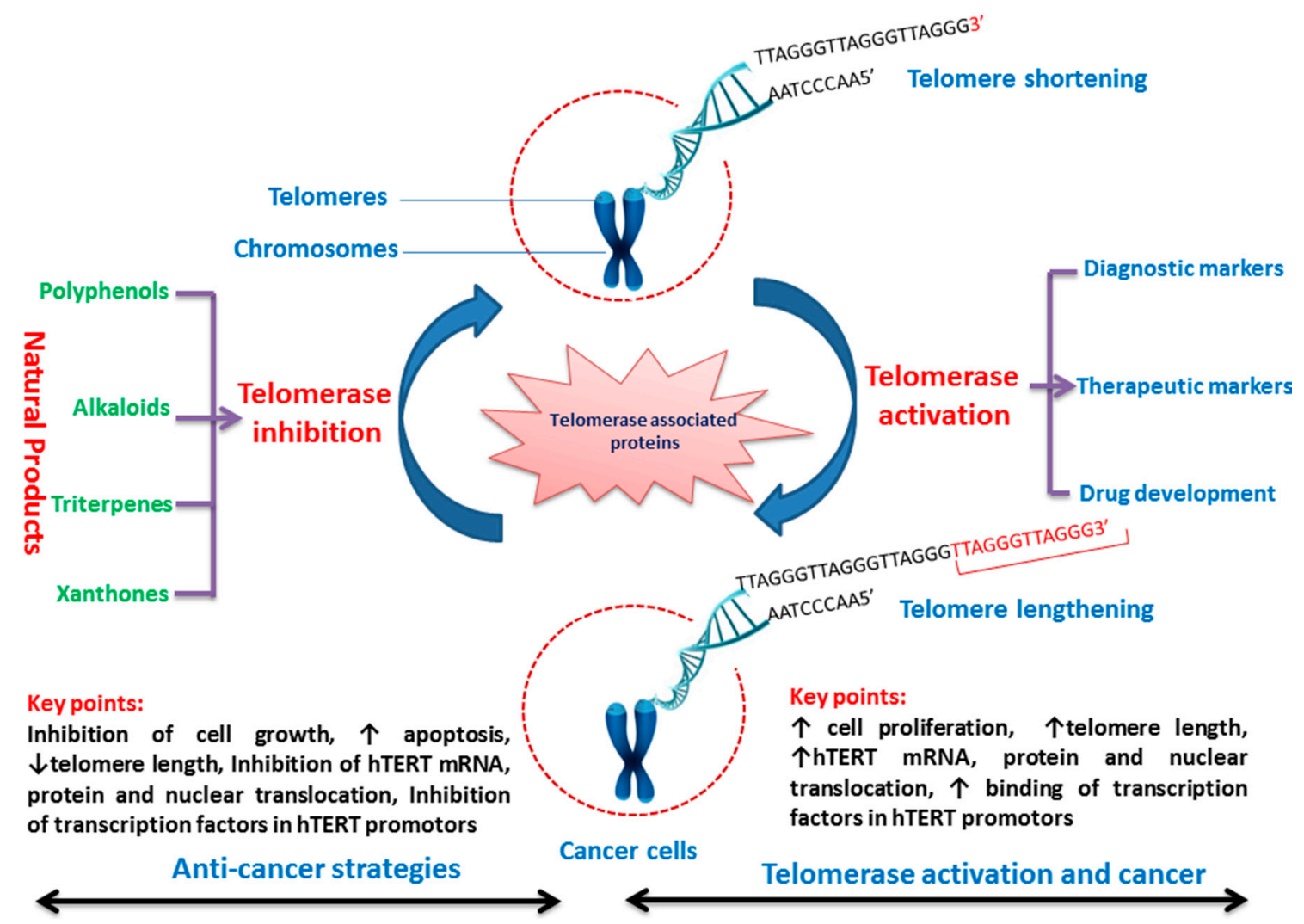

Figure 1. Telomerase-related anticancer strategies by natural products. $\uparrow:$ increase; $\downarrow$ : decrease; hTERT: human telomerase reverse transcriptase.

\section{Expression of Telomerase in Cancer Cells}

The levels of telomerase activity in the early and late stage of cancer might be used to determine the diagnosis of various human cancers (Table 2). Based on the levels of this enzyme, tumor behavior such as differentiation and metastasis of cells could be determined. The higher expressions of telomerase activity in cells have been associated with poor differentiation and higher mortality incidence in patients with adenocarcinoma and small cell cancer of the lung [49,50]. Similarly, high expression of telomerase is found in patients with breast cancer (86\%) [51], colorectal cancers (80-90\%) [52] and gastrointestinal cancer (70\%) [53]. The expression of telomerase in most cancer cells is directly proportional to the expression of hTERT mRNA [54,55]. Nevertheless, some cancer cells do not express telomerase. For incidence in breast cancer cells, there is a higher expression of hTERT mRNA and protein without active telomerase [56]. In another study, a high expression of hTERT mRNA with telomerase activity was demonstrated with advanced stages of colonic adenocarcinoma and endometrial cancer [57]. These findings relate to a high degree of malignancy that could be used as a diagnostic marker to detect cancer with high recurrence rate [58]. 
Table 2. Diagnostic and therapeutic implications of telomerase and telomerase inhibition on various human cancers.

\begin{tabular}{|c|c|c|c|}
\hline Cancer & Findings & Implications & References \\
\hline \multicolumn{4}{|c|}{ Diagnostic Implications of Telomerase Activity } \\
\hline Breast & $\begin{array}{l}\text { The telomerase activity in breast fine-needle } \\
\text { aspirates has higher sensitivity ( } 86 \% \text { vs. } 70 \% \text { for } \\
\text { cytology) and is detectable in stage } 1 \text { cancer cells. }\end{array}$ & $\begin{array}{l}\text { Telomerase assays might play a potentially } \\
\text { useful adjunct role in noninvasive screening and } \\
\text { diagnosis of breast cancer. }\end{array}$ & [51] \\
\hline Cervix & $\begin{array}{l}\text { Telomerase activity is expressed in cervical fluid } \\
\text { of patients. }\end{array}$ & $\begin{array}{l}\text { Telomerase assay gives a promising diagnostic } \\
\text { biomarker for early cervical cancer detection. }\end{array}$ & [54] \\
\hline Colon & $\begin{array}{l}\text { Telomerase is detected in the intestinal fluid of } \\
\text { patients }(80-90 \%) \text { with colorectal carcinoma. }\end{array}$ & $\begin{array}{l}\text { Telomerase assay holds great promising as a } \\
\text { diagnostic biomarker for early colon cancer } \\
\text { detection and monitoring and has considerable } \\
\text { potential for developing anticancer therapy. }\end{array}$ & {$[52,59]$} \\
\hline Kidney & $\begin{array}{l}\text { Telomerase activity is expressed in kidney } \\
\text { abscess of patients }(77 \%) \text { with kidney carcinoma. }\end{array}$ & $\begin{array}{l}\text { Telomerase assay gives a promising diagnostic } \\
\text { biomarker for kidney cancer detection. }\end{array}$ & [60] \\
\hline $\begin{array}{l}\text { Liver and } \\
\text { biliary }\end{array}$ & $\begin{array}{l}\text { Telomerase activity is expressed in liver and } \\
\text { biliary abscess of patients }(70 \%) \text { with liver and } \\
\text { biliary carcinoma. }\end{array}$ & $\begin{array}{l}\text { Telomerase assay gives a promising diagnostic } \\
\text { biomarker for early liver cancer detection. }\end{array}$ & {$[53,61]$} \\
\hline Lung & $\begin{array}{l}\text { The telomerase activity and circulating tumor } \\
\text { cells in lung adenocarcinoma fluid has a higher } \\
\text { sensitivity ( } 78 \% \text { vs. } 65 \% \text { for circulating } \\
\text { tumor cells). }\end{array}$ & $\begin{array}{l}\text { The combination of the circulating tumor cells } \\
\text { and telomerase assays provide high sensitivity in } \\
\text { lung adenocarcinoma diagnosis and follow up. }\end{array}$ & [62] \\
\hline Pancreas & $\begin{array}{l}\text { Telomerase activity is expressed in pancreas fluid } \\
\text { and abscess of patients ( } 82 \% \text { and } 85 \% \text { ) with } \\
\text { prostate carcinoma. }\end{array}$ & $\begin{array}{l}\text { Telomerase assay gives a promising diagnostic } \\
\text { biomarker for pancreatic cancer detection. }\end{array}$ & {$[55,63]$} \\
\hline Prostate & $\begin{array}{l}\text { Telomerase activity is expressed in prostate } \\
\text { abscess of patients }(75 \%) \text { with } \\
\text { prostate carcinoma. }\end{array}$ & $\begin{array}{l}\text { Telomerase assay gives a promising diagnostic } \\
\text { biomarker for early prostate cancer detection. }\end{array}$ & [64] \\
\hline Thyroid & $\begin{array}{l}\text { Telomerase activity is expressed in thyroid } \\
\text { abscess of patients ( } 80 \%) \text { with thyroid carcinoma. }\end{array}$ & $\begin{array}{l}\text { Telomerase assay gives a promising diagnostic } \\
\text { biomarker for early thyroid cancer detection. }\end{array}$ & {$[65,66]$} \\
\hline $\begin{array}{l}\text { Urinary } \\
\text { bladder }\end{array}$ & $\begin{array}{l}\text { Telomerase activity is expressed in bladder } \\
\text { abscess of patients }(80 \%) \text { with } \\
\text { bladder carcinoma. }\end{array}$ & $\begin{array}{l}\text { Telomerase assays might play a potentially } \\
\text { useful adjunct role in noninvasive screening and } \\
\text { diagnosis of bladder cancer. }\end{array}$ & {$[67,68]$} \\
\hline Uterine & $\begin{array}{l}\text { Telomerase activity is expressed in uterine } \\
\text { abscess of patients }(90 \%) \text { with liver and } \\
\text { biliary carcinoma. }\end{array}$ & $\begin{array}{l}\text { Telomerase assay gives a promising diagnostic } \\
\text { biomarker for early uterine cancer detection. }\end{array}$ & [69] \\
\hline \multicolumn{4}{|c|}{ Therapeutic Implications of Telomerase Inhibition in Human Cancers by Natural Products } \\
\hline Breast & $\begin{array}{l}\text { Treatment with Melissa officinalis extract can } \\
\text { inhibit telomerase activity in human breast } \\
\text { cancer cell line. }\end{array}$ & \multirow{7}{*}{$\begin{array}{l}\text { Telomerase inhibition might be useful in the } \\
\text { treatment of various cancers with } \\
\text { telomerase-positive cells. }\end{array}$} & [70] \\
\hline Cervical & $\begin{array}{l}\text { Treatment with (-)-epigallocatechin gallate can } \\
\text { inhibit telomerase activity in human cervical } \\
\text { cancer cell line. }\end{array}$ & & [71] \\
\hline Colon & $\begin{array}{l}\text { Treatment with Morus Rubra extract can inhibit } \\
\text { telomerase activity in human colon cancer } \\
\text { cell line. }\end{array}$ & & [72] \\
\hline Liver & $\begin{array}{l}\text { Treatment with Atractylis lancea (Thunb.) DC } \\
\text { extract can inhibit telomerase activity in human } \\
\text { liver cancer cell line. }\end{array}$ & & [73] \\
\hline Lung & $\begin{array}{l}\text { Treatment with Melissa officinalis extract can } \\
\text { inhibit telomerase activity in human lung } \\
\text { adenocarcinoma cell line. }\end{array}$ & & [70] \\
\hline Prostate & $\begin{array}{l}\text { Treatment with Melissa officinalis extract can } \\
\text { inhibit telomerase activity in human prostate } \\
\text { cancer cell line. }\end{array}$ & & [70] \\
\hline Uterine & $\begin{array}{l}\text { Treatment with phenolic-rich extracts from Savda } \\
\text { Munziq can inhibit telomerase activity in human } \\
\text { uterine cancer cell line. }\end{array}$ & & [74] \\
\hline
\end{tabular}

Telomerase activity in cancer cells is normally inhibited by various natural products, and this inhibition has been connected with the decrease of cell viability [74]. The therapeutic effect of natural products on various cancers decreases telomerase activity by down-regulation of the hTERT mRNA expression, apoptosis induction and induce senescence via the DNA damage response. In addition, 
these natural products activate p53 expression that inhibits cell cycle, migration and metastatic ability [70,72]. Therapeutic implications of telomerase in various human cancers by natural products on various human cancers are listed in Table 2.

\section{Telomerase Inhibitors from Natural Products}

Telomerase inhibitors, commonly derived from natural plant materials, include secondary metabolites such as polyphenols, alkaloids, terpenoids, xanthones, and sesquiterpene [75-77]. Plant metabolites are potential therapeutic compounds, which mainly target telomerase inhibition including hTERT and hTR, telomerase substrates, and their associated proteins [78-81]. In an anti-telomerase screening study, plant secondary metabolites play a vital role in reducing telomerase activity and induce apoptosis $[75,82,83]$. Various in vivo and in vitro studies exhibit that secondary metabolites have a cytotoxic potential for telomerase inhibition and anti-proliferative properties. Anticancer potentials of natural products from plants on targeting telomerase are listed in Table 3.

Table 3. Anticancer potentials of natural products from plants on targeting telomerase.

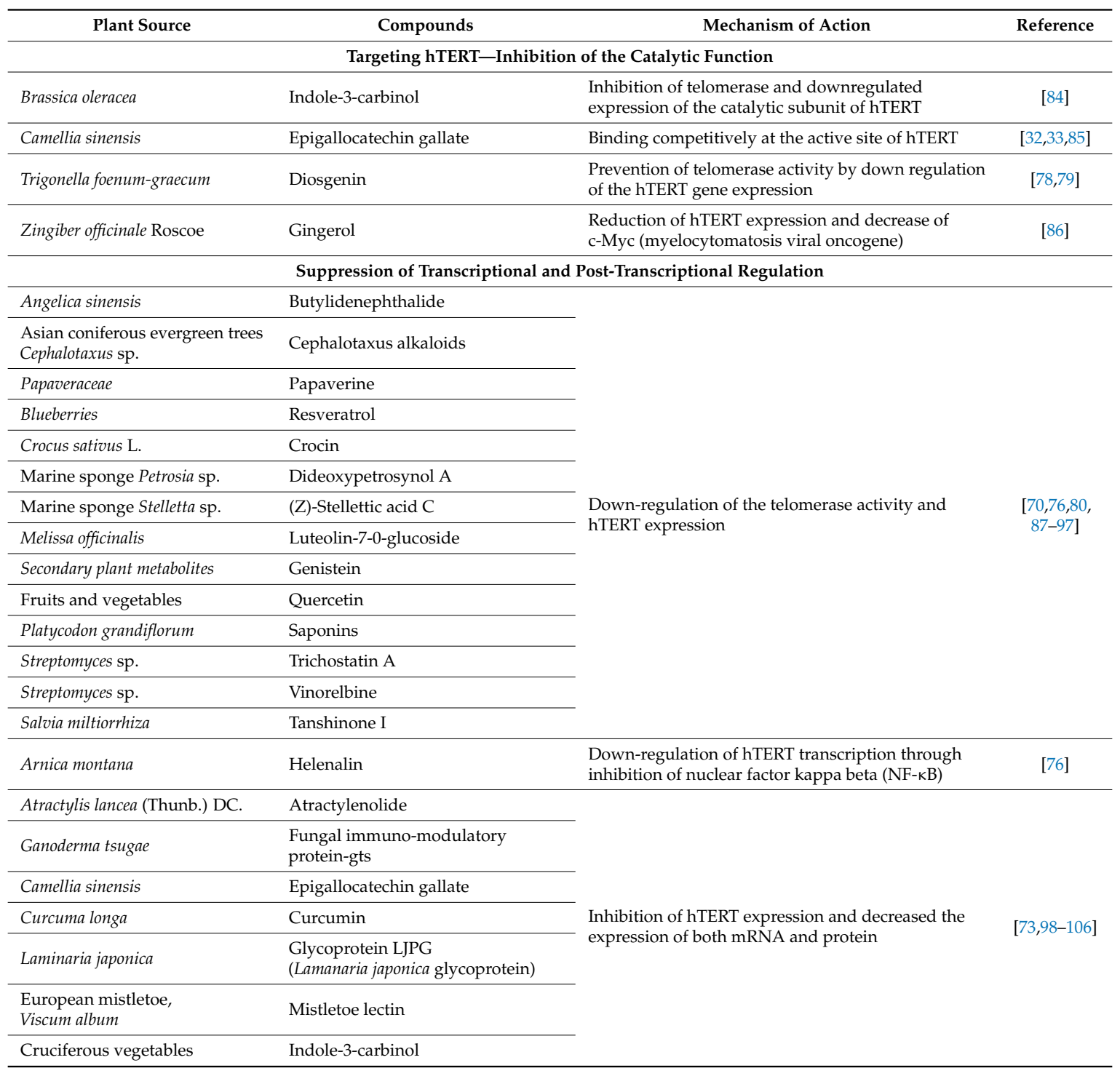


Table 3. Cont

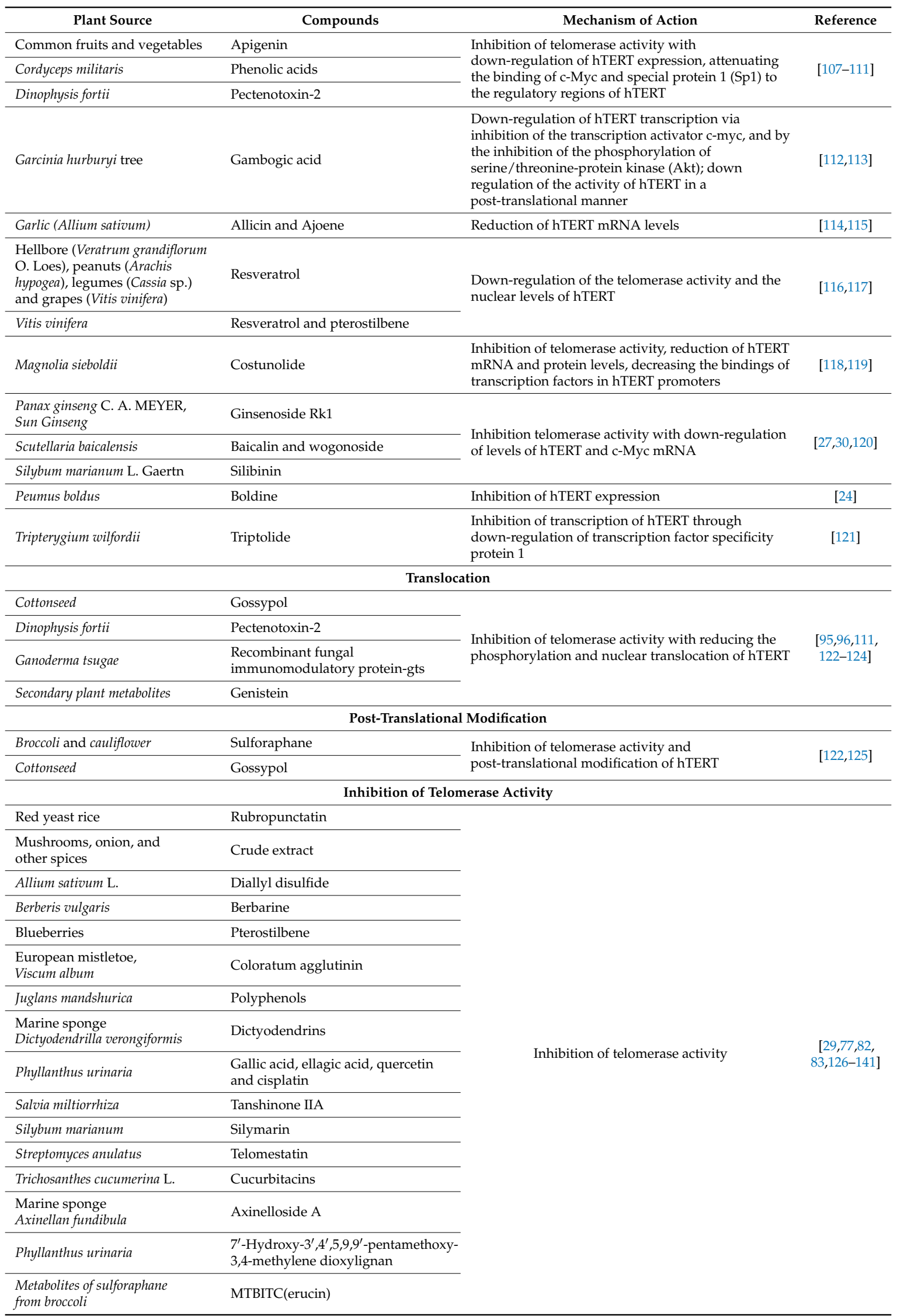


Table 3. Cont.

\begin{tabular}{|c|c|c|c|}
\hline Plant Source & Compounds & Mechanism of Action & Reference \\
\hline Brassica oleracea & $\begin{array}{l}\text { Indole-3-carbinol and } \\
\text { 3,3'-diindolylmethane }\end{array}$ & & \\
\hline Diterpenoid quinone & Salvicine & \multirow{2}{*}{$\begin{array}{l}\text { Induce apoptosis and Inhibition of } \\
\text { telomerase activity }\end{array}$} & \multirow{2}{*}{$\begin{array}{c}{[114,142,} \\
143]\end{array}$} \\
\hline Garlic (Allium sativum) & Allicin and Ajoene & & \\
\hline Glycine max & Daidzein & \multirow{4}{*}{$\begin{array}{l}\text { Inhibition of cell growth and cell cycle in } \mathrm{G} 2 / \mathrm{M} \\
\text { phase. Induce apoptosis and Inhibition of telomerase } \\
\text { activity and reduced telomere length }\end{array}$} & \multirow{4}{*}{$\begin{array}{c}{[38,39,144,} \\
145]\end{array}$} \\
\hline $\begin{array}{l}\text { Panax ginseng C.A. Meyer } \\
\text { Radix rubra }\end{array}$ & Korean red ginseng & & \\
\hline Platycodon grandiflorum & Platycodin & & \\
\hline Pedicularis striata Pall & Verbascoside & & \\
\hline \multicolumn{4}{|c|}{ Targeting the Telomerase Substrate and Associated Protein-Competitor for Substrate } \\
\hline Camellia sinensis & Epigallocatechin gallate & $\begin{array}{l}\text { Binding competitively with respect to the RNA } \\
\text { substrate primer }\end{array}$ & {$[32,33,85]$} \\
\hline \multicolumn{4}{|c|}{ G4 DNA-Interactive Compounds } \\
\hline Ascidian Amphicarpa meridian & Meridine & \multirow{4}{*}{$\begin{array}{l}\text { Inhibition of telomerase activity and stabilization } \\
\text { of G4 }\end{array}$} & \multirow{4}{*}{$\begin{array}{l}{[37,43,44,} \\
146-153]\end{array}$} \\
\hline $\begin{array}{l}\text { Berberis vulgaris chinensis (Coptis } \\
\text { or goldenthread) }\end{array}$ & Berberine & & \\
\hline Cryptolepis triangularis & Cryptolepine & & \\
\hline Glycine max & Daidzin & & \\
\hline Coptidis rhizoma & Palmatine & \multirow{2}{*}{ Formation of C-myc22 G4 and Hum24 G4 } & \multirow{2}{*}[44,154]{} \\
\hline $\begin{array}{l}\text { North American herb bloodroot } \\
\text { (Sanguinaria canadensis) }\end{array}$ & Sanguinarine & & \\
\hline
\end{tabular}

\subsection{Polyphenols}

\subsubsection{Curcumin}

Curcumin, one of the primary components in dried rhizome of turmeric (Curcuma longa L.), possesses anti-proliferating and anti-carcinogenic properties. Various studies have shown that curcumin plays a potential role in cancer prevention as well as in inducing apoptosis, and has anti-inflammatory activities through modulation of the redox status of the cell [155-158]. A study conducted by Cui et al. [159] investigated the potential role of curcumin as chemoprevention/chemotherapy for various human cancer cell lines (Bel7402, HL60, and SGC7901). They indicated that curcumin in a dose-dependent manner showed the direct inhibitory impact on cell proliferation and suppress telomerase activity in all those cancer cell lines. A similar study conducted by Chakraborty et al. [160] in leukemia cell line K-562 and Mukherjee Nee Chakraborty [102] in leukemia cell lines K-562 and HL-60 that the curcumin plays a vital role in cancer prevention and treatment by inhibiting telomerase activity, suppressing of cell viability and inducing apoptosis. In another study, Ramachandran et al. [101] also reported that curcumin can inhibit telomerase activity in michigan cancer foundation-7 (MCF-7) breast cancer cells, which may be due to down-regulation of hTERT and myelocytomatosis viral oncogene (c-myc) mRNA expression. With respect to the researchers on the effect of curcumin on nuclear localization of telomerase, Lee and Chung [161] reported that curcumin induces down-regulation of hTERT and 
dissociates the binding of hTERT with p23 and thereby regulates the nuclear localization of telomerase. By inhibition of nuclear translocation of hTERT during tumorigenic progression, curcumin suppresses telomerase activity. Hsin et al. [162] administered curcumin to adenocarcinomic human alveolar basal epithelial cells (A-549) and observed its anticancer activity. They emphasize that one of the mechanisms used by curcumin is its inducing of reactive oxygen species (ROS) production, resulting in inhibition of special protein 1 (Sp1) binding activity and downregulation of hTERT. Singh and Singh [163] showed that curcumin, in a dose-dependent manner, induces apoptosis and cytotoxic effects in human cervical cancer cell lines (HeLa, SiHa, CaSki, and C33A) pretreatment with estradiol. Higher doses of curcumin are administered to the cells, which counteract the proliferative response of estradiol that induces apoptosis. Based on the studies related to cancer cell lines, it can be proven that curcumin is a potential inducer of apoptosis and suppressor of telomerase activity.

\subsubsection{Quercetin}

Quercetin is a naturally occurring polyphenol from the flavonoid groups found in most fruits (apples, grapes, berries, cherries, red wine, and citrus), vegetables (onion, tomato, sweet potato radish, capers, broccoli, and fennel), green tea, and food grains. Studies show that quercetin exhibits anti-proliferative and pro-apoptotic effects as well as anti-carcinogenic properties. Quercetin is a well-known autophagy mediator that inhibits cell proliferation by inducing cell cycle arrest, cell migration, colony formation and eventually, suppress the cancer cell progression [164,165]. Several studies demonstrate that quercetin can play an important function in cancer treatment and prevention by inhibiting telomerase activity and inducing apoptosis [166-168]. In colon cancer, the inhibition of growth and telomerase activity is provoked by treatment with estrogen receptor beta ligands such as quercetin and tamoxifen [169]. In a study in 2001, Choi et al. [170] stated that growth inhibition is provoked by quercetin in MCF-7 cell lines by at least two different mechanisms. Primarily, quercetin arrests the cell cycle through transient $M$ phase accumulation followed by G2 phase arrest. Secondly, quercetin induces apoptosis. Similarly, the mechanism associated with quercetin inducing apoptosis and cytotoxic effects were observed in human promyelocytic leukemia cells (HL-60) by Kang and Seung-Eun [109] and human lung cancer cell lines by Kuo et al. [171]. They found that administration of quercetin at higher concentrations was completely arrested cell proliferation. Similarly, Lee et al. [172] administered quercetin in a dose-dependent manner to human leukemic monocyte lymphoma cells and observed increased DNA fragmentation, apoptosis and G2/M phase arrest. With respect to the research on the impact of quercetin on apoptosis, Kou [173] and Gibellini et al. [174] found that quercetin in a dose-dependent manner induces apoptosis, arrest the cells at different cycles and block their growth in various cancer cells. In addition, several animal studies have also been conducted and they found the mechanisms of chemopreventive and therapeutic effects of quercetin [175-178]. The epidemiological studies also reported that the regular consumption of quercetin (1.01-31.7 mg/day) could reduce the ovarian cancer risk [179]. Furthermore, in vivo and in vitro studies suggested that quercetin exerts anti-carcinogenic potential through inhibiting angiogenesis and tumor growth, cell cycle arrest, and inducing apoptosis $[180,181]$. The impact of quercetin synergizes with epigallocatechin gallate (EGCG) show anticancer potentials including death receptor 5 upregulation, activation of p53, inhibition of cell cycle, and caspase-induced apoptosis [182]. Avci et al. [167] also reported that quercetin has anti-proliferative and apoptotic effects on cells in various leukemias, such as T-cell acute lymphoblastic, acute promyelocytic, and chronic myeloid. In this study, quercetin reduces telomerase activity and apoptosis-mediated cell death and thereby it is proven as a therapeutic agent for the treatment of leukemia. Furthermore, quercetin, in a dose-dependent manner, prevents various cancer cell line growth such as lung [183], stomach [184], colon [185], nasopharyngeal [186], laryngeal [187], brain [188] and breast [189], which reduce telomerase activity, down-regulated hTERT expression and induce apoptosis. Based on various studies related cancer cell line, it can be proven that quercetin is a potential inducer of apoptosis and 
suppressor of telomerase activity. This result shows quercetin has a potential anti-carcinogenic effect through this mechanism.

\subsubsection{Resveratrol}

Resveratrol (3,5,4'-trihydroxy-trans-stilbene) is a natural phenolic phytoalexin compound produced by various plants and in the skin of fruits, including peanut, grape, mulberry, strawberry, raspberry, and blackberry. Various studies have investigated the effect of resveratrol on telomerase inhibition activity and down-regulation of hTERT protein expression in various cancer cell lines [190-192]. In recent years, telomerase has become a significant therapeutic target in various cancers; inhibition of telomerase can induce senescence via the DNA damage response. Additionally, in this study, hTERT played a significant role in direct and indirect control of cell survival upon the regulation of p53 genes that function in apoptosis [192]. Treatment with Pterostilbene, as a natural analog of resveratrol, significantly decreases telomerase activity and protein expression in lung cancer cell line H460 (p53 wild-type) compared with H1299 (p53 null) cells and p53 knockdown H460 cells (H460-p53-) [192]. Another study has also shown that the effect of resveratrol on telomerase activity in human colorectal cancer cell lines [193]. Resveratrol inhibited the cell proliferation of HT-29 and WiDr cell lines and down-regulated telomerase activity in a dose-dependent manner. This study has further demonstrated that colorectal cancer has a close relationship with hTERT mRNA expression and high telomerase activity. Normally, "hTERT mRNA" is the key subunit of telomerase enzyme that is expressed in more than $85 \%$ of cancer cells, including melanoma [25], breast cancer [117,191] and adenocarcinoma [168]. In addition, resveratrol has a potential role in chemoprevention/chemotherapy for oral diseases [194], breast cancer [88] and skin carcinogenesis [195]. The chemopreventive potential of resveratrol has been attributed to a variety of mechanisms, including its general inhibition of phase I metabolism and induction of phase II metabolism [196]. Further, anticancer properties of resveratrol have shown direct inhibitory actions on the growth and proliferation of various cell, and inducing apoptosis. In this study, pterostilbene reduced the catalytic functions of telomerase, inhibited cell growth, arrested cell proliferation at S-phase and induced signaling pathways of apoptosis [192]. Studies further show that hTERT catalytic subunit can provoke telomerase activity as a result of its post-translational phosphorylation [94,125] and nuclear translocation [27,96]. Resveratrol inhibits the promoter activity of hTERT and prevented the proliferation of cells in colon cancer [197]. Zhai et al. [198] have examined the impacts of resveratrol on apoptosis, telomerase ability, and hTERT in A431 human epidermoid carcinoma cell line. In this study, resveratrol was more effective in reducing cell viability, significantly inhibited the ability of telomerase, and reduced the expression of hTERT protein in a dose-dependent manner. Pterostilbene possesses potent antitumor activity against several human cancer cell types, and is found in various plant species. Molecular docking studies have shown that pterostilbene interacts with and has high affinity for an active site of telomerase [128]. Furthermore, this study showed that the treatment of pterostilbene in MCF7 and NCI-H460 cancer cell lines exhibits significant inhibition of telomerase activity after $72 \mathrm{~h} \mathrm{[128].}$

\subsubsection{Tannic Acid}

Tannic acid (TA) is a naturally occurring polyphenol found in red wine, grapes, beans, tea, coffee, nuts and various vegetables and fruits. Several studies have shown that TA has a potential activity in cancer prevention [199-204]. Cosan et al. [168] have investigated the impacts of TA on telomerase activity, cell viability, number of cells and DNA fragmentation in human breast (MCF-7) and human colon cancer ( $\mathrm{CaCo}-2)$ cell lines. TA is effective in reducing telomerase activity, cell viability and cell count in breast and colon adenocarcinoma. Zielińska-Przyjemska et al. [199] have also reported that the anti-cancer potential of tannic acid provokes the induction of apoptosis and cell cycle in rat C6 and human T98G glioma cells. TA provokes apoptosis, which has been confirmed by phosphatidylserine externalization, cleaved caspase-3 level and loss of membrane potential in mitochondria. Other studies also found that TA arrested the cell cycle and increased the percentage of 
cells in the SubG1 phase in some cancer cell lines [201,205,206]. In addition, TA could protect against skin tumor promotion induced by UV radiation in an in vivo study [207]. Tietbohl et al. [208] have found that TA possesses anti-proliferative properties, which was tested in vitro against seven human cancer cells and immortalized skin keratinocytes. Animal studies have also shown that regular dietary consumption of TA has strongly demonstrated dose-dependent chemopreventive actions against hepatic tumor development and enhances the survival rate [209-211].

One of the significant TA in green tea is (-)-epigallocatechin-3-gallate (EGCG), which has been demonstrated in multiple types of cancer [212-214]. EGCG is a naturally occurring polyphenol from the catechin group found in tea (green, white and black), fruits (apples and plums), vegetables (onions and carobs) and nuts (hazelnuts and pecans). EGCG possibly induces apoptosis and telomerase inhibition activity, and provokes mitochondrial membrane potential and caspase- 3 expression in various cancer cells [215-217]. In addition, EGCG has down-regulated the mRNA and protein expression of hTERT and c-Myc protein [218]. Low cytotoxic dose EGCG and (-)-epigallocatechin (EGC) have suppressed hTERT expression on reporter system and hTERT mRNA level in various cancers [213,214]. Liu et al. [217] reported that EGCG induces apoptosis by down-regulating hTERT and B cell lymphoma 2 (Bcl-2), arresting cells in both G2/M and S phase and promoting DNA damage response specifically in ovarian cancer cell lines.

\subsection{Alkaloids}

\subsubsection{Boldine}

Boldine (1,10-dimethoxy-2,9-dihydroxy aporphine) is a natural aporphine alkaloid richly found in the boldo tree (Peumus boldus) and in lindera (Lindera aggregata). It exhibits a dose- and time-dependent cytotoxic and anti-tumor effect against various cell lines, such as liver (HepG-2), bladder (T24), and brain (U138-MG, U87-MG, and C6). The treatment with boldine in these cell lines concomitantly reduces telomerase activity, induces apoptosis and down-regulates hTERT gene expression [24,219-221]. A study conducted by Paydar et al. [222] in human invasive breast cancer cell lines (MDA-MB-231) and animal model shows that boldine induces cell cycle arrest at the G2/M phase and induces apoptosis, as indicated by a release of lactate dehydrogenase, membrane permeability, and DNA fragmentation. These studies promote boldine as a significant candidate for telomerase-targeted cancer and could be potent anti-cancer therapy.

\subsubsection{Berberine}

Berberine is a benzylisoquinoline alkaloid, isolated from the roots, rhizomes, and stem bark of various plants, including Berberis vulgaris (barberry), Tinospora cordifolia, Xanthorhiza simplicissima (yellowroot), and Coptis chinensis (Chinese goldthread). Due to its strong yellow fluorescence, it has been decorated in the festival history of China and India, and widely used as a natural dye [223]. Previous studies conducted by Wu et al. [224] in HL-60 human leukemia cells and Naasani et al. [225] in U937 human leukemia cells show that berberine induces apoptosis with down-regulation of nucleophosmin/B23 mRNA and telomerase activity. Telomerase activity was reduced to about 35\% and $63 \%$ after incubation with berberine $(15 \mu \mathrm{g} / \mathrm{mL})$ for 48 and $96 \mathrm{~h}$, respectively. In a 2006 study, Franceschin et al. [37] stated that the inhibitory effects of berberine keeps in its preference for binding G4 with duplex DNA to become stable G4. In another study, Ji et al. [44] also reported the formation of G4 by telomeric DNA and C-Myc22 sequences, which interact with berberine and other 9 plant alkaloids. Similar studies associated with anti-telomerase effects of berberine and formation of G-quadruplex of telomeric DNA are reported by many researchers [226-228]. The stabilization of G4 is an important phenomenon to halt cancer cell proliferation and has been considered as a potential drug target for cancer. In this aspect, berberine is a strong affinity with G4, resulting in inhibitory effects on the telomerase activity and amplification of telo21 DNA. 


\subsection{Triterpenoid}

\subsubsection{Pristimerin}

Pristimerin is a quinone methide triterpenoid isolated from several plant species in the Celastraceae and Hippocrateaceae families that have been known to have a variety of biological activities, including chemopreventive or chemotherapeutic potentials. It has been shown to possess antiproliferative effect on various human cancer cell lines, such as breast, lung, prostate, cervical and multiple myeloma tumors [229-233]. Pristimerin inhibits telomerase activity and hTERT mRNA expression resulting in the suppression of native and phosphorylated hTERT protein [213]. Furthermore, the results revealed that the inhibition of hTERT mRNA expression is attributed to the inhibition of transcription factors and protein kinase that regulate hTERT post-translationally. In another study, Deeb et al. [234] also reported that pristimerin can inhibit telomerase and cell proliferative activities, arrest cells in the G1 phase and induce apoptosis in pancreatic ductal adenocarcinoma cells. Pristimerin inhibits hTERT expression by reducing the transcription factors and nuclear factor kappa beta (NF- $\mathrm{kB}$ ), which control hTERT gene expression. Based on the data evidence, pristimerin is a potential drug candidate for various types of cancers.

\subsubsection{Oleanane}

Oleanane (Methyl-2-cyano-3,12-dioxooleana-1,9(11)-dien-28-oate is a triterpenoid derivative of oleanolic acid with potent anti-inflammatory, anti-tumorigenic and apoptosis-inducing potential in various tumor cell lines such as breast, brain, prostate, lung, leukemia, multiple myeloma, and osteosarcoma $[235,236]$. Oleanane inhibits cell proliferation and telomerase suppression activity, hTERT gene expression, and a number of hTERT-regulatory protein expressions in pancreatic and prostate cancer cells $[237,238]$. Collectively, these results suggest that telomerase (hTERT) is a relevant target candidate of oleanane for the prevention and treatment of prostate and pancreatic cancers.

\subsection{Xanthones}

Gambogic Acid and Gambogenic Acid

Gambogic acid and gambogenic acid are two major secondary metabolites belonging to a family of caged xanthones which are found in gamboge resin of the Garcinia hurburyi tree. They have been used as coloring substances based on their unique colors. In vitro and in vivo studies have shown that gambogic acid and gambogenic acid have a broad spectrum of cytotoxic activities on numerous cancer cell lines such as prostate, leukemia, stomach, lung, breast, liver, and pancreas [239-242]. With respect to the researchers on the impact of both gambogic and gambogenic acid on apoptosis, $\mathrm{Li}$ et al. [243] and $\mathrm{Fu}$ et al. [244] reported that gambogic acid and gambogenic acid treatment significantly inhibit the proliferation of several tumor cell lines in vitro and in vivo based on doses and time. Both compounds induce apoptosis, arrest the cells at the G0/G1 phase and down-regulate the cyclin D1 and cyclooxygenase-2 expression in mRNA level. In addition, in vivo, antitelomerase activity and anticancer effects have further been shown by applying xenografts in nude mice. Several kinds of research demonstrate that gambogic acid and gambogenic acid play a significant role in prevention and treatment of cancer by suppressing telomerase activity and inducing apoptosis and thereby cell cycle arrest. Guo et al. [245] and Yu et al. [246] also reported that both compounds have potential anticancer properties, as they induce apoptosis, reduce telomerase activity and down-regulate hTERT in a post-translational manner through inhibition of the transcription activators and serine/threonine-protein kinase (Akt). Taken together, these data suggest that both compounds have antioxidant potential and may be useful, especially in combination therapies, for treating various cancers. 


\section{Conclusions}

Telomerase is a diagnostic and therapeutic biomarker because it is absent from most somatic cells and is present in most cancer cells. The relationship between telomerase and cancer is complex, which makes it a distinctive target for cancer therapy. Telomerase synergistically with natural products may play a crucial role in the development of a drug for cancer therapy. Recent research clearly demonstrates that the impacts of natural compounds inhibit telomerase activity, inhibit cell proliferation, reduce hTERT mRNA and protein and subsequently promote apoptosis in various cancer cell lines. Researchers further suggest that natural products alter telomerase activity by suppression at transcriptional and post-transcriptional levels. We showed the possible relationship between natural products and working regulation of telomerase and its various binding proteins to inhibit the telomere/telomerase complex. Based on the investigation, this review concludes that natural compounds such as polyphenols, alkaloids, triterpenes, and xanthones are potential chemopreventive and chemotherapeutic agents for the treatment of cancer.

Acknowledgments: The work was jointly supported by two grants (R201627 and R201714) from Beijing Normal University-Hong Kong Baptist University United International College, Zhuhai, Guangdong, China.

Author Contributions: Kumar Ganesan and Baojun Xu conceived and designed the review; Kumar Ganesan wrote the paper; and Baojun Xu critically revised and improved the manuscript.

Conflicts of Interest: The authors declared that no conflicts of interest.

\section{References}

1. Popli, D.B.; Sircar, K.; Chowdhry, A. Telomerase: An exploration toward the end of cancer. Indian J. Dent. Res. 2017, 28, 574-584. [CrossRef] [PubMed]

2. Zhang, M.Y.; Wang, J.P. A multi-target protein of hTERTR-FAM96A presents significant anticancer potent in the treatment of hepatocellular carcinoma. Tumour Biol. 2017, 39. [CrossRef] [PubMed]

3. Ivancich, M.; Schrank, Z.; Wojdyla, L.; Leviskas, B.; Kuckovic, A.; Sanjali, A.; Puri, N. Treating cancer by targeting telomeres and telomerase. Antioxidants 2017, 6. [CrossRef] [PubMed]

4. Chung, S.S.; Adekoya, D.; Enenmoh, I.; Clarke, O.; Wang, P.; Sarkyssian, M.; Wu, Y.; Vadgama, J.V. Salinomycin abolished STAT3 and STAT1 interactions and reduced telomerase activity in colorectal cancer cells. Anticancer Res. 2017, 37, 445-453. [CrossRef] [PubMed]

5. Odago, F.O.; Gerson, S.L. Telomerase inhibition and telomere erosion: A two-pronged strategy in cancer therapy. Trends Pharmacol. Sci. 2003, 24, 328-331. [CrossRef]

6. Parkinson, E.K. Telomerase as a novel and potentially selective target for cancer chemotherapy. Ann. Med. 2003, 35, 466-475. [CrossRef] [PubMed]

7. Cian, A.D.; Lacroix, L.; Douarre, C.; Temime-Smaali, N.; Trentesaux, C.; Riou, J.F.; Mergny, J.L. Targeting telomeres and telomerase. Biochimie 2008, 90, 131-155. [CrossRef] [PubMed]

8. Autexier, C.; Lue, N.F. The structure and function of telomerase reverse transcriptase. Ann. Rev. Biochem. 2006, 75, 493-517. [CrossRef] [PubMed]

9. Hiyama, E.; Hiyama, K. Telomere and telomerase in stem cells. Br. J. Cancer 2007, 96, 1020-1024. [CrossRef] [PubMed]

10. Masutomi, K.; Possemato, R.; Wong, J.M.Y.; Currier, J.L.; Tothova, Z.; Manola, J.B.; Ganesan, S.; Lansdorp, P.M.; Collins, K.; Hahn, W.C. The telomerase reverse transcriptase regulates chromatin state and DNA damage responses. Proc. Natl. Acad. Sci. USA 2005, 102, 8222-8227. [CrossRef] [PubMed]

11. Atkinson, S.P.; Hoare, S.F.; Glasspool, R.M.; Keith, W.N. Lack of telomerase gene expression in alternative lengthening of telomere cells is associated with chromatin remodeling of the hTR and hTERT gene promoters. Cancer Res. 2005, 65, 7585-7590. [CrossRef] [PubMed]

12. Hanahan, D.; Weinberg, R.A. The hallmarks of cancer. Cell 2000, 100, 57-70. [CrossRef]

13. Bisoffi, M.; Heaphy, C.M.; Griffith, J.K. Telomeres: Prognostic markers for solid tumors. Int. J. Cancer 2006, 119, 2255-2260. [CrossRef] [PubMed] 
14. Kazemi-Lomedasht, F.; Rami, A.; Zarghami, N. Comparison of inhibitory effect of curcumin nanoparticles and free curcumin in human telomerase reverse transcriptase gene expression in breast cancer. Adv. Pharm. Bull. 2013, 3, 127-130. [PubMed]

15. Badrzadeh, F.; Akbarzadeh, A.; Zarghami, N.; Yamchi, M.R.; Zeighamian, V.; Tabatabae, F.S.; Taheri, M.; Kafil, H.S. Comparison between effects of free curcumin and curcumin loaded NIPAAm-MAA nanoparticles on telomerase and PinX1 gene expression in lung cancer cells. Asian Pac. J. Cancer Prev. 2014, 15, 8931-8936. [CrossRef] [PubMed]

16. Nasiri, M.; Zarghami, N.; Koshki, K.N.; Mollazadeh, M.; Moghaddam, M.P.; Yamchi, M.R.; Esfahlan, R.J.; Barkhordari, A.; Alibakhshi, A. Curcumin and silibinin inhibit telomerase expression in T47D human breast cancer cells. Asian Pac. J. Cancer Prev. 2013, 14, 3449-3453. [CrossRef] [PubMed]

17. Chan, S.W.-L.; Blackburn, E.H. New ways not to make ends meet: Telomerase, DNA damage proteins and heterochromatin. Oncogene 2002, 21, 553-563. [CrossRef] [PubMed]

18. Celli, G.B.; de Lange, T. DNA processing is not required for ATM mediated telomere damage response after TRF2 deletion. Nat. Cell Biol. 2005, 7, 712-718. [CrossRef] [PubMed]

19. De Lange, T. How telomeres solve the end-protection problem. Science 2009, 326, 948-952. [CrossRef] [PubMed]

20. Sfeir, A.; Kabir, S.; van Overbeek, M.; Celli, G.B.; de Lange, T. Loss of Rap1 induces telomere recombination in the absence of NHEJ or a DNA damage signal. Science 2010, 327, 1657-1661. [CrossRef] [PubMed]

21. Lai, K.H.; Liu, Y.C.; Su, J.H.; El-Shazly, M.; Wu, C.F.; Du, Y.C.; Hsu, Y.M.; Yang, J.C.; Weng, M.K.; Chou, C.H.; et al. Antileukemic scalarane sesterterpenoids and meroditerpenoid from Carteriospongia (Phyllospongia) sp., induce apoptosis via dual inhibitory effects on topoisomerase II and Hsp90. Sci. Rep. 2016, 6, 36170. [CrossRef] [PubMed]

22. Chini, M.G.; Malafronte, N.; Vaccaro, M.C.; Gualtieri, M.J.; Vassallo, A.; Vasaturo, M.; Castellano, S.; Milite, C.; Leone, A.; Bifulco, G.; et al. Identification of limonol derivatives as heat shock protein 90 (Hsp90) inhibitors through a multidisciplinary approach. Chemistry 2016, 22, 13236-13250. [CrossRef] [PubMed]

23. Zhang, Z.; Xue, N.; Bian, C.; Yan, R.; Jin, L.; Chen, X.; Yu, X. C15-methoxyphenylated 18-deoxy-herbimycin A analogues, their in vitro anticancer activity and heat shock protein 90 binding affinity. Bioorg. Med. Chem. Lett. 2016, 26, 4287-4291. [CrossRef] [PubMed]

24. Noureini, S.K.; Tanavar, F. Boldine, a natural aporphine alkaloid, inhibits telomerase at non-toxic concentrations. Chem. Biol. Interact. 2015, 231, 27-34. [CrossRef] [PubMed]

25. Platella, C.; Guida, S.; Bonmassar, L.; Aquino, A.; Bonmassar, E.; Ravagnan, G.; Montesarchio, D.; Roviello, G.N.; Musumeci, D.; Fuggetta, M.P. Antitumour activity of resveratrol on human melanoma cells: A possible mechanism related to its interaction with malignant cell telomerase. Biochim. Biophys. Acta 2017, 1861, 2843-2851. [CrossRef] [PubMed]

26. Han, M.H.; Lee, D.S.; Jeong, J.W.; Hong, S.H.; Choi, I.W.; Cha, H.J.; Kim, S.; Kim, H.S.; Park, C.; Kim, G.Y.; et al. Fucoidan induces ROS-dependent apoptosis in 5637 human bladder cancer cells by downregulating telomerase activity via inactivation of the PI3K/Akt signaling pathway. Drug Dev. Res. 2017, 78, 37-48. [CrossRef] [PubMed]

27. Kim, Y.J.; Kwon, H.C.; Ko, H.; Park, J.H.; Kim, H.Y.; Yoo, J.H.; Yang, H.O. Anti-tumor activity of the ginsenoside Rk1 in human hepatocellular carcinoma cells through inhibition of telomerase activity and induction of apoptosis. Biol. Pharm. Bull. 2008, 31, 826-830. [CrossRef] [PubMed]

28. Moirangthem, D.S.; Laishram, S.; Borah, J.C.; Kalita, M.C.; Talukdar, N.C. Cephalotaxus griffithii Hook.f. needle extract induces cell cycle arrest, apoptosis and suppression of hTERT and hTR expression on human breast cancer cells. BMC Complement. Altern. Med. 2014, 14, 305. [CrossRef] [PubMed]

29. Huang, S.T.; Wang, C.Y.; Yang, R.C.; Chu, C.J.; Wu, H.T.; Pang, J.H. Phyllanthus urinaria increases apoptosis and reduces telomerase activity in human nasopharyngeal carcinoma cells. Forsch. Komplementmed. 2009, 16, 34-40. [CrossRef] [PubMed]

30. Huang, S.T.; Wang, C.Y.; Yang, R.C.; Chu, C.J.; Wu, H.T.; Pang, J.H. Wogonin, an active compound in Scutellaria baicalensis, induces apoptosis and reduces telomerase activity in the HL-60 leukemia cells. Phytomedicine 2010, 17, 47-54. [CrossRef] [PubMed]

31. Woo, H.J.; Choi, Y.H. Growth inhibition of A549 human lung carcinoma cells by beta-lapachone through induction of apoptosis and inhibition of telomerase activity. Int. J. Oncol. 2005, 26, 1017-1023. [PubMed] 
32. Oyama, J.I.; Shiraki, A.; Nishikido, T.; Maeda, T.; Komoda, H.; Shimizu, T.; Makino, N.; Node, K. EGCG, a green tea catechin, attenuates the progression of heart failure induced by the heart/muscle-specific deletion of MnSOD in mice. J. Cardiol. 2017, 69, 417-427. [CrossRef] [PubMed]

33. Nagle, D.G.; Ferreira, D.; Zhou, Y.D. Epigallocatechin-3-gallate (EGCG): Chemical and biomedical perspectives. Phytochemistry 2006, 67, 1849-1855. [CrossRef] [PubMed]

34. Liao, C.Y.; Lee, C.L.; Wang, H.C.; Liang, S.S.; Kung, P.H.; Wu, Y.C.; Chang, F.R.; Wu, C.C. CLL2-1, a chemical derivative of orchid 1,4-phenanthrenequinones, inhibits human platelet aggregation through thiol modification of calcium-diacylglycerol guanine nucleotide exchange factor-I (CalDAG-GEFI). Free Radic. Biol. Med. 2015, 78, 101-110. [CrossRef] [PubMed]

35. Sheremet, M.; Kapoor, S.; Schröder, P.; Kumar, K.; Ziegler, S.; Waldmann, H. Small molecules inspired by the natural product withanolides as potent inhibitors of Wnt signaling. Chembiochem 2017, 18, 1797-1806. [CrossRef] [PubMed]

36. Han, L.; Bian, H.; Ouyang, J.; Bi, Y.; Yang, L.; Ye, S. Wenyang Huazhuo Tongluo formula, a Chinese herbal decoction, improves skin fibrosis by promoting apoptosis and inhibiting proliferation through down-regulation of survivin and cyclin D1 in systemic sclerosis. BMC Complement. Altern. Med. 2016, 16. [CrossRef] [PubMed]

37. Franceschin, M.; Rossetti, L.; D’Ambrosio, A.; Schirripa, S.; Bianco, A.; Ortaggi, G.; Savino, M.; Schultes, C.; Neidle, S. Natural and synthetic G-quadruplex interactive berberine derivatives. Bioorg. Med. Chem. Lett. 2006, 16, 1707-1711. [CrossRef] [PubMed]

38. Kim, M.O.; Moon, D.O.; Choi, Y.H.; Shin, D.Y.; Kang, H.S.; Choi, B.T.; Lee, J.D.; Li, W.; Kim, G.Y. Platycodin D induces apoptosis and decreases telomerase activity in human leukemia cells. Cancer Lett. 2008, 261, 98-107. [CrossRef] [PubMed]

39. Park, S.E.; Park, C.; Kim, S.H.; Hossain, M.A.; Kim, M.Y.; Chung, H.Y.; Son, W.S.; Kim, G.Y.; Choi, Y.H.; Kim, N.D. Korean red ginseng extract induces apoptosis and decreases telomerase activity in human leukemia cells. J. Ethnopharmacol. 2009, 121, 304-312. [CrossRef] [PubMed]

40. Chiruvella, K.K.; Raghavan, S.C. A natural compound, methyl angolensate, induces mitochondrial pathway of apoptosis in Daudi cells. Invest. New Drugs 2011, 29, 583-592. [CrossRef] [PubMed]

41. Feng, H.; Guo, B.; Kong, X.; Wu, B. Evodiamine enhances the radiosensitivity of esophageal squamous cell cancer Eca-109 cells. Xi Bao Yu Fen Zi Mian Yi Xue Za Zhi 2016, 32, 940-944. [PubMed]

42. Shirode, A.B.; Kovvuru, P.; Chittur, S.V.; Henning, S.M.; Heber, D.; Reliene, R. Antiproliferative effects of pomegranate extract in MCF-7 breast cancer cells are associated with reduced DNA repair gene expression and induction of double strand breaks. Mol. Carcinog. 2014, 53, 458-470. [CrossRef] [PubMed]

43. Pan, X.H.C.; Zeng, F.; Zhang, S.; Xu, J. Isolation and identification of alkaloids from Menispermum dauricum growing in Xianning. Zhong Yao Cai 1998, 21, 456-458. [PubMed]

44. Ji, X.; Sun, H.; Zhou, H.; Xiang, J.; Tang, Y.; Zhao, C. The interaction of telomeric DNA and C-myc22 G-quadruplex with 11 natural alkaloids. Nucleic Acid Ther. 2012, 22, 127-136. [PubMed]

45. Kumari, S.; Nayak, G.; Lukose, S.T.; Kalthur, S.G.; Bhat, N.; Hegde, A.R.; Mutalik, S.; Kalthur, G.; Adiga, S.K. Indian propolis ameliorates the mitomycin C-induced testicular toxicity by reducing DNA damage and elevating the antioxidant activity. Biomed. Pharmacother. 2017, 95, 252-263. [CrossRef] [PubMed]

46. Hajjar, D.; Kremb, S.; Sioud, S.; Emwas, A.H.; Voolstra, C.R.; Ravasi, T. Anti-cancer agents in Saudi Arabian herbals revealed by automated high-content imaging. PLoS ONE 2017, 12, e0177316. [CrossRef] [PubMed]

47. Sun, M.F.; Chang, T.T.; Chang, K.W.; Huang, H.J.; Chen, H.Y.; Tsai, F.J.; Lin, J.G.; Chen, C.Y. Blocking the DNA repair system by traditional Chinese medicine? J. Biomol. Struct. Dyn. 2011, 28, 895-906. [CrossRef] [PubMed]

48. Alam, F.; Us Saqib, Q.N.; Waheed, A. Cytotoxic activity of extracts and crude saponins from Zanthoxylum armatum DC. against human breast (MCF-7, MDA-MB-468) and colorectal (Caco-2) cancer cell lines. BMC Complement. Altern. Med. 2017, 17, 368. [CrossRef] [PubMed]

49. Sarvesvaran, J.; Going, J.J.; Milroy, R.; Kaye, S.B.; Keith, W.N. Is small cell lung cancer the perfect target for anti-telomerase treatment? Carcinogenesis 1999, 20, 1649-1651. [CrossRef] [PubMed]

50. Kumaki, F.; Kawai, T.; Hiroi, S.; Shinomiya, N.; Ozeki, Y.; Ferrans, V.J.; Torikata, C. Telomerase activity and expression of human telomerase RNA component and human telomerase reverse transcriptase in lung carcinomas. Hum. Pathol. 2001, 32, 188-195. [CrossRef] [PubMed] 
51. Oztas, E.; Kara, H.; Kara, Z.P.; Aydogan, M.U.; Uras, C.; Ozhan, G. Association between human telomerase reverse transcriptase gene variations and risk of developing breast cancer. Genet. Test. Mol. Biomarkers 2016, 20, 459-464. [CrossRef] [PubMed]

52. Shi, M.; Zheng, J.; Liu, C.; Tan, G.; Qing, Z.; Yang, S.; Yang, J.; Tan, Y.; Yang, R. SERS assay of telomerase activity at single-cell level and colon cancer tissues via quadratic signal amplification. Biosens. Bioelectron. 2016, 77, 673-680. [CrossRef] [PubMed]

53. Yu, S.A.; Peng, C.H.; Wu, R.J.; Zheng, Z.D.; Chen, K.; Fu, Z.N. Detection of telomerase activity of exfoliated cells in bile and its clinical impact. Ai Zheng 2002, 21, 177-180. [PubMed]

54. Barbosa, L.C.; da Silva, I.D.; Corrêa, J.C.; Ribalta, J.C. Survivin and telomerase expression in the uterine cervix of women with human papillomavirus-induced lesions. Int. J. Gynecol. Cancer 2011, 21, 15-21. [CrossRef] [PubMed]

55. Wang, S.; Chen, X.; Tang, M. Quantitative assessment of the diagnostic role of human telomerase activity from pancreatic juice in pancreatic cancer. Tumour Biol. 2014, 35, 7897-7904. [CrossRef] [PubMed]

56. Yano, Y.; Yoshida, K.; Osaki, A.; Toge, T.; Tahara, H.; Ide, T.; Yasui, W. Expression and distribution of human telomerase catalytic component, hTERT, in human breast tissues. Anticancer Res. 2002, 22, 4101-4107. [PubMed]

57. Boldrini, L.; Faviana, P.; Gisfredi, S.; Zucconi, Y.; Di Quirico, D.; Donati, V.; Berti, P.; Spisni, R.; Galleri, D.; Materazzi, G.; et al. Evaluation of telomerase mRNA (hTERT) in colon cancer. Int. J. Oncol. 2002, 21, $493-497$. [CrossRef] [PubMed]

58. Bonatz, G.; Frahm, S.O.; Klapper, W.; Helfenstein, A.; Heidorn, K.; Jonat, W.; Krupp, G.; Parwaresch, R.; Rudolph, P. High telomerase activity is associated with cell cycle deregulation and rapid progression in endometrioid adenocarcinoma of the uterus. Hum. Pathol. 2001, 32, 605-614. [CrossRef] [PubMed]

59. Chen, C.H.; Chen, R.J. Prevalence of telomerase activity in human cancer. J. Formos. Med. Assoc. 2011, 110, 275-289. [CrossRef]

60. Sidorova, N.; Zavalishina, L.; Kurchashova, S.; Korsakova, N.; Nazhimov, V.; Frank, G.; Kuimov, A. Immunohistochemical detection of tankyrase 2 in human breast tumors and normal renal tissue. Cell Tissue Res. 2006, 323, 137-145. [CrossRef] [PubMed]

61. Itoi, T.; Shinohara, Y.; Takeda, K.; Nakamura, K.; Shimizu, M.; Ohyashiki, K.; Hisatomi, H.; Nakano, H.; Moriyasu, F. Detection of telomerase reverse transcriptase mRNA in biopsy specimens and bile for diagnosis of biliary tract cancers. Int. J. Mol. Med. 2001, 7, 281-287. [CrossRef] [PubMed]

62. Man, Y.; Cao, J.; Jin, S.; Xu, G.; Pan, B.; Shang, L.; Che, D.; Yu, Q.; Yu, Y. Newly identified biomarkers for detecting circulating tumor cells in lung adenocarcinoma. Tohoku J. Exp. Med. 2014, 234, 29-40. [CrossRef] [PubMed]

63. Hilal, G.; Reitzel, R.; Al Hamal, Z.; Chaftari, A.M.; Al Wohoush, I.; Jiang, Y.; Hachem, R.; Raad, I.I. Novel plasma telomerase detection method to improve cancer diagnostic assessment. PLoS ONE 2017, 12, e0174266. [CrossRef] [PubMed]

64. Glybochko, P.V.; Zezerov, E.G.; Glukhov, A.I.; Alyaev, Y.G.; Severin, S.E.; Polyakovsky, K.A.; Varshavsky, V.A.; Severin, E.S.; Vinarov, A.Z. Telomerase as a tumor marker in diagnosis of prostatic intraepithelial neoplasia and prostate cancer. Prostate 2014, 74, 1043-1051. [CrossRef] [PubMed]

65. Mora, J.; Lerma, E. Thyroid Neoplasia Study Group. Telomerase activity in thyroid fine needle aspirates. Acta Cytol. 2004, 48, 818-824. [CrossRef] [PubMed]

66. Capezzone, M.; Marchisotta, S.; Cantara, S.; Pacini, F. Telomeres and thyroid cancer. Curr. Genom. 2009, 10, 526-533. [CrossRef] [PubMed]

67. Koonrungsesomboon, N.; Wadagni, A.C.; Mbanefo, E.C. Molecular markers and Schistosoma-associated bladder carcinoma: A systematic review and meta-analysis. Cancer Epidemiol. 2015, 39, 487-496. [CrossRef] [PubMed]

68. Lou, X.; Zhuang, Y.; Zuo, X.; Jia, Y.; Hong, Y.; Min, X.; Zhang, Z.; Xu, X.; Liu, N.; Xia, F.; et al. Real-time, quantitative lighting-up detection of telomerase in urines of bladder cancer patients by AIEgens. Anal. Chem. 2015, 87, 6822-6827. [CrossRef] [PubMed]

69. Hapangama, D.K.; Kamal, A.; Saretzki, G. Implications of telomeres and telomerase in endometrial pathology. Hum. Reprod. Update 2017, 23, 166-187. [CrossRef] [PubMed] 
70. Jahanban-Esfahlan, R.; Seidi, K.; Monfaredan, A.; Shafie-Irannejad, V.; Abbasi, M.M.; Karimian, A.; Yousefi, B. The herbal medicine Melissa officinalis extract effects on gene expression of p53, Bcl-2, Her2, VEGF-A and hTERT in human lung, breast and prostate cancer cell lines. Gene 2017, 613, 14-19. [CrossRef] [PubMed]

71. Noguchi, M.; Yokoyama, M.; Watanabe, S.; Uchiyama, M.; Nakao, Y.; Hara, K.; Iwasaka, T. Inhibitory effect of the tea polyphenol, (-)-epigallocatechin gallate, on growth of cervical adenocarcinoma cell lines. Cancer Lett. 2006, 234, 135-142. [CrossRef] [PubMed]

72. Demir, S.; Turan, I.; Aliyazicioglu, Y.; Kilinc, K.; Yaman, S.O.; Ayazoglu Demir, E.; Arslan, A.; Mentese, A.; Deger, O. Morus rubra extract induces cell cycle arrest and apoptosis in human colon cancer cells through endoplasmic reticulum stress and telomerase. Nutr. Cancer 2017, 69, 74-83. [CrossRef] [PubMed]

73. Guo, W.Q.; Li, L.Z.; He, Z.Y.; Zhang, Q.; Liu, J.; Hu, C.Y.; Qin, F.J.; Wang, T.Y. Anti-proliferative effects of Atractylis lancea (Thunb.) DC. via down-regulation of the c-myc/hTERT/telomerase pathway in Hep-G2 cells. Asian Pac. J. Cancer Prev. 2013, 14, 6363-6367. [CrossRef] [PubMed]

74. Abliz, G.; Mijit, F.; Hua, L.; Abdixkur, G.; Ablimit, T.; Amat, N.; Upur, H. Anti-carcinogenic effects of the phenolic-rich extract from abnormal Savda Munziq in association with its cytotoxicity, apoptosis-inducing properties and telomerase activity in human cervical cancer cells (SiHa). BMC Complement. Altern. Med. 2015, 15, 23. [CrossRef] [PubMed]

75. Xu, B.; Sung, C.K. Screening of Telomerase Inhibitor from Natural Products and Their Anticancer Activities. Ph.D. Thesis, Chungnam National University, Taejon, Korea, 5 February 2005.

76. Chen, J.L.-Y.; Sperry, J.; Ip, N.Y.; Brimble, M.A. Natural products targeting telomere maintenance. MedChemComm 2011, 2, 229. [CrossRef]

77. Xu, B.; Wang, Q.; Sung, C.K. Telomerase inhibitory effects of red pigment rubropunctatin and Statin monacolin $\mathrm{L}$ isolated from red yeast rice. Genes 2017, 8, 129. [CrossRef] [PubMed]

78. Mohammad, R.Y.; Somayyeh, G.; Gholamreza, H.; Majid, M.; Yousef, R. Diosgenin inhibits hTERT gene expression in the A549 lung cancer cell line. Asian Pac. J. Cancer Prev. 2013, 14, 6945-6948. [CrossRef] [PubMed]

79. Rahmati-Yamchi, M.; Ghareghomi, S.; Haddadchi, G.; Milani, M.; Aghazadeh, M.; Daroushnejad, H. Fenugreek extract diosgenin and pure diosgenin inhibit the hTERT gene expression in A549 lung cancer cell line. Mol. Biol. Rep. 2014, 41, 6247-6252. [CrossRef] [PubMed]

80. Noureini, S.K.; Wink, M. Antiproliferative effect of the isoquinoline alkaloid papaverine in hepatocarcinoma HepG-2 cells-Inhibition of telomerase and induction of senescence. Molecules 2014, 19, 11846-11859. [CrossRef] [PubMed]

81. Chen, Y.; Zhang, Y. Functional and mechanistic analysis of telomerase: An antitumor drug target. Pharmacol. Ther. 2016, 163, 24-47. [CrossRef] [PubMed]

82. Xu, B.; Li, C.; Sung, C.K. Telomerase inhibitory effects of medicinal mushrooms and lichens, and their anticancer activity. Int. J. Med. Mushrooms 2014, 16, 17-28. [CrossRef] [PubMed]

83. Xu, B.; Sung, C.K. Telomerase inhibitory effects and anti-proliferative properties of onion and other natural spices against cancer cells. Food Biosci. 2015, 10, 80-85. [CrossRef]

84. Marconett, C.N.; Sundar, S.N.; Tseng, M.; Tin, A.S.; Tran, K.Q.; Mahuron, K.M.; Bjeldanes, L.F.; Firestone, G.L. Indole-3-carbinol downregulation of telomerase gene expression requires the inhibition of estrogen receptor-alpha and Sp1 transcription factor interactions within the hTERT promoter and mediates the G1 cell cycle arrest of human breast cancer cells. Carcinogenesis 2011, 32, 1315-1323. [CrossRef] [PubMed]

85. Lin, S.C.; Li, W.C.; Shih, J.W.; Hong, K.F.; Pan, Y.R.; Lin, J.J. The tea polyphenols EGCG and EGC repress mRNA expression of human telomerase reverse transcriptase (hTERT) in carcinoma cells. Cancer Lett. 2006, 236, 80-88. [CrossRef] [PubMed]

86. Tuntiwechapikul, W.; Taka, T.; Songsomboon, C.; Kaewtunjai, N.; Imsumran, A.; Makonkawkeyoon, L.; Pompimon, W.; Lee, T.R. Ginger extract inhibits human telomerase reverse transcriptase and c-Myc expression in A549 lung cancer cells. J. Med. Food 2010, 13, 1347-1354. [CrossRef] [PubMed]

87. Lin, P.C.; Lin, S.Z.; Chen, Y.L.; Chang, J.S.; Ho, L.I.; Liu, P.Y.; Chang, L.F.; Harn, Y.C.; Chen, S.P.; Sun, L.Y.; et al. Butylidenephthalide suppresses human telomerase reverse transcriptase (TERT) in human glioblastomas. Ann. Surg. Oncol. 2011, 18, 3514-3527. [CrossRef] [PubMed]

88. Lanzilli, G.; Fuggetta, M.P.; Tricarico, M.; Cottarelli, A.; Serafino, A.; Falchetti, R.; Ravagnan, G.; Turriziani, M.; Adamo, R.; Franzese, O.; et al. Resveratrol down-regulates the growth and telomerase activity of breast cancer cells in vitro. Int. J. Oncol. 2006, 28, 641-648. [CrossRef] [PubMed] 
89. Noureini, S.K.; Wink, M. Antiproliferative effects of crocin in HepG2 cells by telomerase inhibition and hTERT down-regulation. Asian Pac. J. Cancer Prev. 2012, 13, 2305-2309. [CrossRef] [PubMed]

90. Verma, A.K.; Pratap, R. The biological potential of flavones. Nat. Prod. Rep. 2010, 27, 1571-1593. [CrossRef] [PubMed]

91. Park, C.; Jung, J.H.; Kim, N.D.; Choi, Y.H. Inhibition of cyclooxygenase-2 and telomerase activities in human leukemia cells by dideoxypetrosynol A, a polyacetylene from the marine sponge Petrosia sp. Int. J. Oncol. 2007, 30, 291-298. [CrossRef] [PubMed]

92. Park, C.; Kim, G.Y.; Kim, W.I.; Hong, S.H.; Park, D.I.; Kim, N.D.; Bae, S.J.; Jung, J.H.; Choi, Y.H. Induction of apoptosis by (Z)-stellettic acid C, an acetylenic acid from the sponge Stelletta sp., is associated with inhibition of telomerase activity in human leukemic U937 cells. Chemotherapy 2007, 53, 160-168. [CrossRef] [PubMed]

93. Park, D.I.; Lee, J.H.; Moon, S.K.; Kim, C.H.; Lee, Y.T.; Cheong, J.; Choi, B.T.; Choi, Y.H. Induction of apoptosis and inhibition of telomerase activity by aqueous extract from Platycodon grandiflorum in human lung carcinoma cells. Pharmacol. Res. 2005, 51, 437-443. [CrossRef] [PubMed]

94. Liu, J.J.; Chen, G.Y.; Wang, M.; Yang, Z.Y.; Hong, X. Effects of vinorelbine on apoptosis and expression of telomerase activity in human lung adenocarcinoma cells in vitro. Zhonghua Zhong Liu Za Zhi 2010, 32, 743-747. [PubMed]

95. Jagadeesh, S.; Kyo, S.; Banerjee, P.P. Genistein represses telomerase activity via both transcriptional and posttranslational mechanisms in human prostate cancer cells. Cancer Res. 2006, 66, 2107-2115. [CrossRef] [PubMed]

96. Li, Y.; Liu, L.; Andrews, L.G.; Tollefsbol, T.O. Genistein depletes telomerase activity through cross-talk between genetic and epigenetic mechanisms. Int. J. Cancer 2009, 125, 286-296. [CrossRef] [PubMed]

97. Woo, H.J.; Lee, S.J.; Choi, B.T.; Park, Y.M.; Choi, Y.H. Induction of apoptosis and inhibition of telomerase activity by trichostatin A, a histone deacetylase inhibitor, in human leukemic U937 cells. Exp. Mol. Pathol. 2007, 82, 77-84. [CrossRef] [PubMed]

98. Mittal, A.; Pate, M.S.; Wylie, R.C.; Tollefsbol, T.O.; Katiyar, S.K. EGCG down-regulates telomerase in human breast carcinoma MCF-7 cells, leading to suppression of cell viability and induction of apoptosis. Int. J. Oncol. 2004, 24, 703-710. [CrossRef] [PubMed]

99. Meeran, S.M.; Patel, S.N.; Chan, T.H.; Tollefsbol, T.O. A novel prodrug of epigallocatechin-3-gallate: Differential epigenetic hTERT repression in human breast cancer cells. Cancer Prev. Res. 2011, 4, 1243-1254. [CrossRef] [PubMed]

100. Adler, S.; Rashid, G.; Klein, A. Indole-3-carbinol inhibits telomerase activity and gene expression in prostate cancer cell lines. Anticancer Res. 2011, 31, 3733-3737. [PubMed]

101. Ramachandran, C.; Fonseca, H.B.; Jhabvala, P.; Escalon, E.A.; Melnick, S.J. Curcumin inhibits telomerase activity through human telomerase reverse transcritpase in MCF-7 breast cancer cell line. Cancer Lett. 2002, 184, 1-6. [CrossRef]

102. Mukherjee Nee Chakraborty, S.; Ghosh, U.; Bhattacharyya, N.P.; Bhattacharya, R.K.; Dey, S.; Roy, M. Curcumin-induced apoptosis in human leukemia cell HL-60 is associated with inhibition of telomerase activity. Mol. Cell. Biochem. 2007, 297, 31-39. [CrossRef] [PubMed]

103. Singh, M.; Singh, N. Molecular mechanism of curcumin induced cytotoxicity in human cervical carcinoma cells. Mol. Cell. Biochem. 2009, 325, 107-119. [CrossRef] [PubMed]

104. Choi, S.H.; Lyu, S.Y.; Park, W.B. Mistletoe lectin induces apoptosis and telomerase inhibition in human A253 cancer cells through dephosphorylation of Akt. Arch. Pharm. Res. 2004, 27, 68-76. [CrossRef] [PubMed]

105. Liao, C.H.; Hsiao, Y.M.; Hsu, C.P.; Lin, M.Y.; Wang, J.C.; Huang, Y.L.; Ko, J.L. Transcriptionally mediated inhibition of telomerase of fungal immunomodulatory protein from Ganoderma tsugae in A549 human lung adenocarcinoma cell line. Mol. Carcinog. 2006, 45, 220-229. [CrossRef] [PubMed]

106. Han, M.H.; Kim, G.Y.; Moon, S.K.; Kim, W.J.; Nam, T.J.; Choi, Y.H. Apoptosis induction by glycoprotein isolated from Laminaria japonica is associated with down-regulation of telomerase activity and prostaglandin E2 synthesis in AGS human gastric cancer cells. Int. J. Oncol. 2011, 38, 577-584. [PubMed]

107. Chakrabarti, M.; Banik, N.L.; Ray, S.K. Sequential hTERT knockdown and apigenin treatment inhibited invasion and proliferation and induced apoptosis in human malignant neuroblastoma SK-N-DZ and SK-N-BE2 cells. J. Mol. Neurosci. 2013, 51, 187-198. [CrossRef] [PubMed] 
108. Jayasooriya, R.G.; Kang, S.H.; Kang, C.H.; Choi, Y.H.; Moon, D.O.; Hyun, J.W.; Chang, W.Y.; Kim, G.Y. Apigenin decreases cell viability and telomerase activity in human leukemia cell lines. Food Chem. Toxicol. 2012, 50, 2605-2611. [CrossRef] [PubMed]

109. Kang, S.-S.; Lim, S.-E. Growth and telomerase inhibition of SK-MEL 28 melanoma cell line by a plant flavonoid, apigenin. BMB Rep. 1998, 31, 339-344.

110. Park, S.E.; Yoo, H.S.; Jin, C.Y.; Hong, S.H.; Lee, Y.W.; Kim, B.W.; Lee, S.H.; Kim, W.J.; Cho, CK.; Choi, Y.H. Induction of apoptosis and inhibition of telomerase activity in human lung carcinoma cells by the water extract of Cordyceps militaris. Food Chem. Toxicol. 2009, 47, 1667-1675. [CrossRef] [PubMed]

111. Vale, P.; de M Sampayo, M.A. Pectenotoxin-2 seco acid, 7-epi-pectenotoxin-2 seco acid and pectenotoxin-2 in shellfish and plankton from Portugal. Toxicon 2002, 40, 979-987. [CrossRef]

112. Han, Q.B.; Xu, H.X. Caged Garcinia xanthones: Development since 1937. Curr. Med. Chem. 2009, 16, 3775-3796. [CrossRef] [PubMed]

113. Yu, J.; Guo, Q.L.; You, Q.D.; Lin, S.S.; Li, Z.; Gu, H.Y.; Zhang, H.W.; Tan, Z.; Wang, X. Repression of telomerase reverse transcriptase mRNA and hTERT promoter by gambogic acid in human gastric carcinoma cells. Cancer Chemother. Pharmacol. 2006, 58, 434-443. [CrossRef] [PubMed]

114. Sun, L.; Wang, X. Effects of allicin on both telomerase activity and apoptosis in gastric cancer SGC-7901 cells. World J. Gastroenterol. 2003, 9, 1930-1934. [CrossRef] [PubMed]

115. Ye, Y.; Yang, H.Y.; Wu, J.; Li, M.; Min, J.M.; Cui, J.R. Z-ajoene causes cell cycle arrest at G2/M and decrease of telomerase activity in HL-60 cells. Zhonghua Zhong Liu Za Zhi 2005, 27, 516-520. [PubMed]

116. Aggarwal, B.B.; Bhardwaj, A.; Aggarwal, R.S.; Seeram, N.P.; Shishodia, S.; Takada, Y. Role of resveratrol in prevention and therapy of cancer: Preclinical and clinical studies. Anticancer Res. 2004, 24, 2783-2840. [PubMed]

117. Kala, R.; Shah, H.N.; Martin, S.L.; Tollefsbol, T.O. Epigenetic-based combinatorial resveratrol and pterostilbene alters DNA damage response by affecting SIRT1 and DNMT enzyme expression, including SIRT1-dependent $\gamma-\mathrm{H} 2 \mathrm{AX}$ and telomerase regulation in triple-negative breast cancer. BMC Cancer 2015, 15, 672. [CrossRef] [PubMed]

118. Kanno, S.; Kitajima, Y.; Kakuta, M.; Osanai, Y.; Kurauchi, K.; Ujibe, M.; Ishikawa, M. Costunolide-induced apoptosis is caused by receptor-mediated pathway and inhibition of telomerase activity in NALM-6 cells. Biol. Pharm. Bull. 2008, 31, 1024-1028. [CrossRef] [PubMed]

119. Choi, S.H.; Im, E.; Kang, H.K.; Lee, J.H.; Kwak, H.S.; Bae, Y.T.; Park, H.J.; Kim, N.D. Inhibitory effects of costunolide on the telomerase activity in human breast carcinoma cells. Cancer Lett. 2005, 227, 153-162. [CrossRef] [PubMed]

120. Thelen, P.; Wuttke, W.; Jarry, H.; Grzmil, M.; Ringert, R.H. Inhibition of telomerase activity and secretion of prostate specific antigen by silibinin in prostate cancer cells. J. Urol. 2004, 171, 1934-1938. [CrossRef] [PubMed]

121. Long, C.; Wang, J.; Guo, W.; Wang, H.; Wang, C.; Liu, Y.; Sun, X. Triptolide inhibits transcription of hTERT through down-regulation of transcription factor specificity protein 1 in primary effusion lymphoma cells. Biochem. Biophys. Res. Commun. 2016, 469, 87-93. [CrossRef] [PubMed]

122. Moon, D.O.; Kim, M.O.; Choi, Y.H.; Lee, H.G.; Kim, N.D.; Kim, G.Y. Gossypol suppresses telomerase activity in human leukemia cells via regulating hTERT. FEBS Lett. 2008, 582, 3367-3373. [CrossRef] [PubMed]

123. Kim, M.O.; Moon, D.O.; Kang, S.H.; Heo, M.S.; Choi, Y.H.; Jung, J.H.; Lee, J.D.; Kim, G.Y. Pectenotoxin-2 represses telomerase activity in human leukemia cells through suppression of hTERT gene expression and Akt-dependent hTERT phosphorylation. FEBS Lett. 2008, 582, 3263-3269. [CrossRef] [PubMed]

124. Liao, C.H.; Hsiao, Y.M.; Sheu, G.T.; Chang, J.T.; Wang, P.H.; Wu, M.F.; Shieh, G.J.; Hsu, C.P.; Ko, J.L. Nuclear translocation of telomerase reverse transcriptase and calcium signaling in repression of telomerase activity in human lung cancer cells by fungal immunomodulatory protein from Ganoderma tsugae. Biochem. Pharmacol. 2007, 74, 1541-1554. [CrossRef] [PubMed]

125. Moon, D.O.; Kang, S.H.; Kim, K.C.; Kim, M.O.; Choi, Y.H.; Kim, G.Y. Sulforaphane decreases viability and telomerase activity in hepatocellular carcinoma Hep3B cells through the reactive oxygen species-dependent pathway. Cancer Lett. 2010, 295, 260-266. [CrossRef] [PubMed]

126. Dasgupta, P.; Sengupta, S.B. Role of diallyl disulfide-mediated cleavage of c-Myc and Sp-1 in the regulation of telomerase activity in human lymphoma cell line U937. Nutrition 2015, 31, 1031-1037. [CrossRef] [PubMed] 
127. Ji, Z.N.; Ye, W.C.; Liu, G.Q.; Huang, Y. Inhibition of telomerase activity and bcl-2 expression in berbamine-induced apoptosis in HL-60 cells. Planta Med. 2002, 68, 596-600. [CrossRef] [PubMed]

128. Tippani, R.; Prakhya, L.J.; Porika, M.; Sirisha, K.; Abbagani, S.; Thammidala, C. Pterostilbene as a potential novel telomerase inhibitor: Molecular docking studies and its in vitro evaluation. Curr. Pharm. Biotechnol. 2014, 14, 1027-1035. [CrossRef] [PubMed]

129. Herz, C.; Tran, H.T.T.; Landerer, S.; Gaus, J.; Schlotz, N.; Lehr, L.; Schäfer, W.R.; Treeck, O.; Odongo, G.A.; Skatchkov, I.; et al. Normal human immune cells are sensitive to telomerase inhibition by Brassica-derived 3, 3-diindolylmethane, partly mediated via ER $\alpha / \beta$-AP1 signaling. Mol. Nutr. Food Res. 2017, 61. [CrossRef] [PubMed]

130. Lin, X.; Cai, Y.-J.; Li, Z.-X.; Chen, Q.; Liu, Z.-L.; Wang, R. Structure determination, apoptosis induction, and telomerase inhibition of CFP-2, a novel lichenin from Cladonia furcata. Biochim. Biophys. Acta 2003, 1622, 99-108. [CrossRef]

131. Lyu, S.Y.; Choi, S.H.; Park, W.B. Korean mistletoe lectin-induced apoptosis in hepatocarcinoma cells is associated with inhibition of telomerase via mitochondrial controlled pathway independent of p53. Arch. Pharm. Res. 2002, 25, 93-101. [CrossRef] [PubMed]

132. Xin, N.; Hasan, M.; Li, W.; Li, Y. Juglans mandshurica Maxim extracts exhibit antitumor activity on HeLa cells in vitro. Mol. Med. Rep. 2014, 9, 1313-1318. [PubMed]

133. Warabi, K.; Matsunaga, S.; van Soest, R.W.; Fusetani, N. Dictyodendrins A-E, the first telomerase-inhibitory marine natural products from the sponge Dictyodendrilla verongiformis. J. Org. Chem. 2003, 68, 2765-2770. [CrossRef] [PubMed]

134. Warabi, K.; Hamada, T.; Nakao, Y.; Matsunaga, S.; Hirota, H.; van Soest, R.W.; Fusetani, N. Axinelloside A, an unprecedented highly sulfated lipopolysaccharide inhibiting telomerase, from the marine sponge, Axinella infundibula. J. Am. Chem. Soc. 2005, 127, 13262-13270. [CrossRef] [PubMed]

135. Herz, C.; Hertrampf, A.; Zimmermann, S.; Stetter, N.; Wagner, M.; Kleinhans, C.; Erlacher, M.; Schuler, J.; Platz, S.; Rohn, S.; et al. The isothiocyanate erucin abrogates telomerase in hepatocellular carcinoma cells in vitro and in an orthotopic xenograft tumour model of HCC. J. Cell Mol. Med. 2014, 18, 2393-2403. [CrossRef] [PubMed]

136. Giridharan, P.; Somasundaram, S.T.; Perumal, K.; Vishwakarma, R.A.; Karthikeyan, N.P.; Velmurugan, R.; Balakrishnan, A. Novel substituted methylenedioxy lignin suppresses proliferation of cancer cells by inhibiting telomerase and activation of c-myc and caspases leading to apoptosis. Br. J. Cancer 2002, 87, 98-105. [CrossRef] [PubMed]

137. Song, Y.Y.S.L.; Yang, Y.M.; Wang, X.J.; Huang, G.Q. Alteration of activities of telomerase in tanshinone IIA inducing apoptosis of the leukemia cells. Zhongguo Zhong Yao Za Zhi 2005, 30, 207-211. [PubMed]

138. Faezizadeh, Z.; Mesbah-Namin, S.A.; Allameh, A. The effect of silymarin on telomerase activity in the human leukemia cell line K562. Planta Med. 2012, 78, 899-902. [CrossRef] [PubMed]

139. Yurtcu, E.; Darcansoy Iseri, O.; Iffet Sahin, F. Effects of silymarin and silymarin-doxorubicin applications on telomerase activity of human hepatocellularcarcinoma cell line HepG2. J. BUON 2015, 20, 555-561. [PubMed]

140. Kim, M.Y.; Vankayalapati, H.; Shin-Ya, K.; Wierzba, K.; Hurley, L.H. Telomestatin, a potent telomerase inhibitor that interacts quite specifically with the human telomeric intramolecular G-quadruplex. J. Am. Chem. Soc. 2002, 124, 2098-2099. [CrossRef] [PubMed]

141. Duangmano, S.; Dakeng, S.; Jiratchariyakul, W.; Suksamrarn, A.; Smith, D.R.; Patmasiriwat, P. Antiproliferative effects of cucurbitacin B in breast cancer cells: Down-regulation of the c-Myc/hTERT/telomerase pathway and obstruction of the cell cycle. Int. J. Mol. Sci. 2010, 11, 5323-5338. [CrossRef] [PubMed]

142. Liu, W.J.; Jiang, J.F.; Xiao, D.; Ding, J. Down-regulation of telomerase activity via protein phosphatase 2A activation in salvicine-induced human leukemia HL-60 cell apoptosis. Biochem. Pharmacol. 2002, 64, 1677-1687. [CrossRef]

143. Yang, Y.; Sun, H.; Zhou, Y.; Ji, S.; Li, M. Effects of three diterpenoids on tumour cell proliferation and telomerase activity. Nat. Prod. Res. 2009, 23, 1007-1012. [CrossRef] [PubMed]

144. Guo, J.M.; Kang, G.Z.; Xiao, B.X.; Li, D.H. Zhang. S. Effect of daidzein on cell growth, cell cycle, and telomerase activity of human cervical cancer in vitro. Int. J. Gynecol. Cancer 2004, 14, 882-888. [CrossRef] [PubMed]

145. Zhang, F.; Jia, Z.; Deng, Z.; Wie, Y.; Zheng, R.; Yu, L. In vitro modulation of telomerase activity, telomere length and cell cycle in MKN45 cells by verbascoside. Planta Med. 2002, 68, 115-118. [CrossRef] [PubMed] 
146. Schmitz, F.J.; DeGuzman, F.S.; Hossain, M.B.; van der Helm, D. Cytotoxic aromatic alkaloids from the ascidian Amphicarpa meridiana and Leptoclinides sp.: Meridine and 11-hydroxyascididemin. J. Org. Chem. 1991, 56, 804-808. [CrossRef]

147. Lu, Q.; Liu, W.; Ding, J.; Cai, J.; Duan, W. Shikonin derivatives: Synthesis and inhibition of human telomerase. Bioorg. Med. Chem. Lett. 2002, 12, 1375-1378. [CrossRef]

148. Guittat, L.; Alberti, P.; Rosu, F.; Van Miert, S.; Thetiot, E.; Pieters, L.; Gabelica, V.; De Pauw, E.; Ottaviani, A.; Riou, J.-F.; et al. Interactions of cryptolepine and neocryptolepine with unusual DNA structures. Biochimie 2003, 85, 535-547. [CrossRef]

149. Li, W.; Zhang, M.; Zhang, J.L.; Li, H.Q.; Zhang, X.C.; Sun, Q.; Qiu, C.M. Interactions of daidzin with intramolecular G-quadruplex. FEBS Lett. 2006, 580, 4905-4910. [CrossRef] [PubMed]

150. Rafii, F. The role of colonic bacteria in the metabolism of the natural isoflavone daidzin to equol. Metabolites 2015, 5, 56-73. [CrossRef] [PubMed]

151. Tomar, J.S. In-silico modeling studies of G-quadruplex with soy isoflavones having anticancerous activity. J. Mol. Model. 2015, 21, 193. [CrossRef] [PubMed]

152. Zhang, J.L.; Fu, Y.; Zheng, L.; Li, W.; Li, H.; Sun, Q.; Xiao, Y.; Geng, F. Natural isoflavones regulate the quadruplex-duplex competition in human telomeric DNA. Nucleic Acids Res. 2009, 37, 2471-2482. [CrossRef] [PubMed]

153. Guittat, L.; De Cian, A.; Rosu, F.; Gabelica, V.; De Pauw, E.; Delfourne, E.; Mergny, J.L. Ascididemin and meridine stabilise G-quadruplexes and inhibit telomerase in vitro. Biochim. Biophys. Acta 2005, 1724, 375-384. [CrossRef] [PubMed]

154. Bai, L.P.; Hagihara, M.; Jiang, Z.H.; Nakatani, K. Ligand binding to tandem G quadruplexes from human telomeric DNA. Chembiochem 2008, 9, 2583-2587. [CrossRef] [PubMed]

155. Banik, U.; Parasuraman, S.; Adhikary, A.K.; Othman, N.H. Curcumin: The spicy modulator of breast carcinogenesis. J. Exp. Clin. Cancer Res. 2017, 36, 98. [CrossRef] [PubMed]

156. Griffiths, K.; Aggarwal, B.B.; Singh, R.B.; Buttar, H.S.; Wilson, D.; De Meester, F. Food antioxidants and their anti-inflammatory properties: A potential role in cardiovascular diseases and cancer prevention. Diseases 2016, 4, 28. [CrossRef]

157. Siddappa, G.; Kulsum, S.; Ravindra, D.R.; Kumar, V.V.; Raju, N.; Raghavan, N.; Sudheendra, H.V.; Sharma, A.; Sunny, S.P.; Jacob, T.; et al. Curcumin and metformin-mediated chemoprevention of oral cancer is associated with inhibition of cancer stem cells. Mol. Carcinog. 2017, 56, 2446-2460. [CrossRef] [PubMed]

158. Wang, X.P.; Wang, Q.X.; Lin, H.P.; Chang, N. Anti-tumor bioactivities of curcumin on mice loaded with gastric carcinoma. Food Funct. 2017, 8, 3319-3326. [CrossRef] [PubMed]

159. Cui, S.X.; Qu, X.J.; Xie, Y.Y.; Zhou, L.; Nakata, M.; Makuuchi, M.; Tang, W. Curcumin inhibits telomerase activity in human cancer cell lines. Int. J. Mol. Med. 2006, 18, 227-231. [CrossRef] [PubMed]

160. Chakraborty, S.; Ghosh, U.; Bhattacharyya, N.P.; Bhattacharya, R.K.; Roy, M. Inhibition of telomerase activity and induction of apoptosis by curcumin in K-562 cells. Mutat. Res. 2006, 596, 81-90. [CrossRef] [PubMed]

161. Lee, J.H.; Chung, I.K. Curcumin inhibits nuclear localization of telomerase by dissociating the Hsp90 co-chaperone p23 from hTERT. Cancer Lett. 2010, 290, 76-86. [CrossRef] [PubMed]

162. Hsin, I.L.; Sheu, G.T.; Chen, H.H.; Chiu, L.Y.; Wang, H.D.; Chan, H.W.; Hsu, C.P.; Ko, J.L. N-acetyl cysteine mitigates curcumin-mediated telomerase inhibition through rescuing of Sp1 reduction in A549 cells. Mutat. Res. 2010, 688, 72-77. [CrossRef] [PubMed]

163. Singh, M.; Singh, N. Curcumin counteracts the proliferative effect of estradiol and induces apoptosis in cervical cancer cells. Mol. Cell. Biochem. 2011, 347, 1-11. [CrossRef] [PubMed]

164. Lou, M.; Zhang, L.N.; Ji, P.G.; Feng, F.Q.; Liu, J.H.; Yang, C.; Li, B.F.; Wang, L. Quercetin nanoparticles induced autophagy and apoptosis through AKT/ERK/Caspase-3 signaling pathway in human neuroglioma cells: In vitro and in vivo. Biomed. Pharmacother. 2016, 84, 1-9. [CrossRef] [PubMed]

165. Ren, K.W.; Li, Y.H.; Wu, G.; Ren, J.Z.; Lu, H.B.; Li, Z.M.; Han, X.W. Quercetin nanoparticles display antitumor activity via proliferation inhibition and apoptosis induction in liver cancer cells. Int. J. Oncol. 2017, 50, 1299-1311. [CrossRef] [PubMed]

166. Naasani, I.; Oh-Hashi, F.; Oh-Hara, T.; Feng, W.Y.; Johnston, J.; Chan, K.; Tsuruo, T. Blocking telomerase by dietary polyphenols is a major mechanism for limiting the growth of human cancer cells in vitro and in vivo. Cancer Res. 2003, 63, 824-830. [PubMed] 
167. Avci, C.B.; Yilmaz, S.; Dogan, Z.O.; Saydam, G.; Dodurga, Y.; Ekiz, H.A.; Kartal, M.; Sahin, F.; Baran, Y.; Gunduz, C. Quercetin-induced apoptosis involves increased hTERT enzyme activity of leukemic cells. Hematology 2011, 16, 303-307. [CrossRef] [PubMed]

168. Cosan, D.T.; Soyocak, A.; Basaran, A.; Degirmenci, I.; Gunes, H.V.; Sahin, F.M. Effects of various agents on DNA fragmentation and telomerase enzyme activities in adenocarcinoma cell lines. Mol. Biol. Rep. 2011, 38, 2463-2469. [CrossRef] [PubMed]

169. Nakayama, Y.; Sakamoto, H.; Satoh, K.; Yamamoto, T. Tamoxifen and gonadal steroids inhibit colon cancer growth in association with inhibition of thymidylate synthase, survivin and telomerase expression through estrogen receptor beta mediated system. Cancer Lett. 2000, 161, 63-71. [CrossRef]

170. Choi, J.A.; Kim, J.Y.; Lee, J.Y.; Kang, C.M.; Kwon, H.J.; Yoo, Y.D.; Kim, T.W.; Lee, Y.S.; Lee, S.J. Induction of cell cycle arrest and apoptosis in human breast cancer cells by quercetin. Int. J. Oncol. 2001, 19, 837-844. [CrossRef] [PubMed]

171. Kuo, P.C.; Liu, H.F.; Chao, J.I. Survivin and p53 Modulate quercetin- induced cell growth inhibition and apoptosis in human lung carcinoma cells. J. Biol. Chem. 2004, 279, 55875-55885. [CrossRef] [PubMed]

172. Lee, T.J.; Kim, O.H.; Kim, Y.H.; Lim, J.H.; Kim, S.; Park, J.W.; Kwon, T.K. Quercetin arrests G2/M phase and induces caspase-dependent cell death in U937 cells. Cancer Lett. 2006, 240, 234-242. [CrossRef] [PubMed]

173. Kou, S.M. Antiproliferative potency of structurally distinct dietary flavonoids on human colon cancer cells. Cancer Lett. 1996, 110, 41-48.

174. Gibellini, L.; Pinti, M.; Nasi, M.; Montagna, J.P.; Biasi, S.D.; Roat, E.; Bertoncelli, L.; Cooper, E.L.; Cossarizza, A. Quercetin and cancer chemoprevention. Evid. Based Complement. Altern. Med. 2011, 2011, 591356. [CrossRef] [PubMed]

175. Cui, Y.; Han, Y.; Yang, X.; Sun, Y.; Zhao, Y. Protective effects of quercetin and quercetin- $5^{\prime}$, 8-disulfonate against carbon tetrachloride-caused oxidative liver injury in mice. Molecules 2013, 19, 291-305. [CrossRef] [PubMed]

176. Yang, C.; Gundala, S.R.; Mukkavilli, R.; Vangala, S.; Reid, M.D.; Aneja, R. Synergistic interactions among flavonoids and acetogenins in Graviola (Annona muricata) leaves confer protection against prostate cancer. Carcinogenesis 2015, 36, 656-665. [CrossRef] [PubMed]

177. Doğan, Z.; Kocahan, S.; Erdemli, E.; Köse, E.; Yılmaz, I.; Ekincioğlu, Z.; Ekinci, N.; Turkoz, Y. Effect of chemotherapy exposure prior to pregnancy on fetal brain tissue and the potential protective role of quercetin. Cytotechnology 2015, 67, 1031-1038. [CrossRef] [PubMed]

178. Oršolić, N.; Karač, I.; Sirovina, D.; Kukolj, M.; Kunštić, M.; Gajski, G.; Garaj-Vrhovac, V.; Štajcar, D. Chemotherapeutic potential of quercetin on human bladder cancer cells. J. Environ. Sci. Health A Tox. Hazard. Subst. Environ. Eng. 2016, 51, 776-781. [CrossRef] [PubMed]

179. Parvaresh, A.; Razavi, R.; Rafie, N.; Ghiasvand, R.; Pourmasoumi, M.; Miraghajani, M. Quercetin and ovarian cancer: An evaluation based on a systematic review. J. Res. Med. Sci. 2016, 21, 34. [CrossRef] [PubMed]

180. Teiten, M.H.; Gaascht, F.; Dicato, M.; Diederich, M. Targeting the wingless signaling pathway with natural compounds as chemopreventive or chemotherapeutic agents. Curr. Pharm. Biotechnol. 2012, 13, 245-254. [CrossRef] [PubMed]

181. Chen, S.F.; Nien, S.; Wu, C.H.; Liu, C.L.; Chang, Y.C.; Lin, Y.S. Reappraisal of the anticancer efficacy of quercetin in oral cancer cells. J. Chin. Med. Assoc. 2013, 76, 146-152. [CrossRef] [PubMed]

182. Tang, S.N.; Singh, C.; Nall, D.; Meeker, D.; Shankar, S.; Srivastava, R.K. The dietary bioflavonoid quercetin synergizes with epigallocathechin gallate (EGCG) to inhibit prostate cancer stem cell characteristics, invasion, migration and epithelialmesenchymal transition. J. Mol. Signal. 2010, 5, 14. [CrossRef] [PubMed]

183. Wang, J.; Zhang, P.H.; Tu, Z.G. Effects of quercetin on proliferation of lung cancer cell line A549 by down-regulating hTERT gene expression. J. Third Mil. Med. Univ. 2007, 29, 1852-1854.

184. Wei, J.W.; Fan, Y.; Zhang, Y.L.; Wu, Y. Effects of quercetin on telomerase activity and apoptosis in gastric cancer cells. Shandong Med. J. 2007, 35, 15.

185. Behjati, M.; Hashemi, M.; Kazemi, M.; Salehi, M.; Javanmard, S.H. Evaluation of energy balance on human telomerase reverse transcriptase (hTERT) alternative splicing by semi-quantitative RT-PCR in human umbilical vein endothelial cells. Adv. Biomed. Res. 2017, 6, 43. [CrossRef] [PubMed]

186. Zheng, D.S.; Chen, L.S. Triterpenoids from Ganoderma lucidum inhibit the activation of EBV antigens as telomerase inhibitors. Exp. Ther. Med. 2017, 14, 3273-3278. [PubMed] 
187. Kuhar, M.; Imran, S.; Singh, N. Curcumin and quercetin combined with cisplatin to induce apoptosis in human laryngeal carcinoma Hep-2 cells through the mitochondrial pathway. J. Cancer Mol. 2007, 3, 121-128.

188. Zamin, L.L.; Filippi-Chiela, E.C.; Dillenburg-Pilla, P.; Horn, F.; Salbego, C.; Lenz, G. Resveratrol and quercetin cooperate to induce senescence-like growth arrest in C6 rat glioma cells. Cancer Sci. 2009, 100, 1655-1662. [CrossRef] [PubMed]

189. Ak, A.; Basaran, A.; Dikmen, M.; Turgut Cosan, D.; Degirmenci, I.; Gunes, H.V. Evaluation of effects of quercetin $\left(3,3^{\prime}, 4^{\prime}, 5,7\right.$-pentohidroxyfl avon) on apoptosis and telomerase enzyme activity in MCF-7 and NIH-3T3 cell lines compared with tamoxifen. Balkan Med. J. 2011, 28, 293-299.

190. Shen, X.; Wang, M.; Bi, X.; Zhang, J.; Wen, S.; Fu, G.; Xia, L. Resveratrol prevents endothelial progenitor cells from senescence and reduces the oxidative reaction via PPAR $\gamma / \mathrm{HO} 1$ pathways. Mol. Med. Rep. 2016, 14, 5528-5534. [CrossRef] [PubMed]

191. Daniel, M.; Tollefsbol, T.O. Pterostilbene down-regulates hTERT at physiological concentrations in breast cancer cells: Potentially through the inhibition of cMyc. J. Cell. Biochem. 2017. [CrossRef] [PubMed]

192. Chen, R.J.; Wu, P.H.; Ho, C.T.; Way, T.D.; Pan, M.H.; Chen, H.M.; Ho, Y.S.; Wang, Y.J. P53-dependent downregulation of hTERT protein expression and telomerase activity induces senescence in lung cancer cells as a result of pterostilbene treatment. Cell Death Dis. 2017, 8, e2985. [CrossRef] [PubMed]

193. Fuggetta, M.P.; Lanzilli, G.; Tricarico, M.; Cottarelli, A.; Falchetti, R.; Ravagnan, G.; Bonmassar, E. Effect of resveratrol on proliferation and telomerase activity of human colon cancer cells in vitro. J. Exp. Clin. Cancer Res. 2006, 25, 189-193. [PubMed]

194. Perrone, D.; Fuggetta, M.P.; Ardito, F.; Cottarelli, A.; De Filippis, A.; Ravagnan, G.; De Maria, S.; Lo Muzio, L. Resveratrol (3, 5, 4'-trihydroxystilbene) and its properties in oral diseases. Exp. Ther. Med. 2017, 14, 3-9. [CrossRef] [PubMed]

195. Aziz, S.W.; Aziz, M.H. Protective molecular mechanisms of resveratrol in UVR-induced skin carcinogenesis. Photodermatol. Photoimmunol. Photomed. 2017. [CrossRef] [PubMed]

196. Guthrie, A.R.; Chow, H.S.; Martinez, J.A. Effects of resveratrol on drug- and carcinogen-metabolizing enzymes, implications for cancer prevention. Pharmacol. Res. Perspect. 2017, 5, e00294. [CrossRef] [PubMed]

197. Wang, X.Y.; Fan, Y.; Zhang, Y.L.; Zhong, X.M. Effect of resveratrol on promoter and human telomerase reverse transcriptase (hTERT) expression of human colorectal carcinoma cell. J. Jiangsu Univ. 2010, 23, 3-23.

198. Zhai, X.X.; Ding, J.C.; Tang, Z.M.; Li, J.G.; Li, Y.C.; Yan, Y.H.; Sun, J.C.; Zhang, C.X. Effects of resveratrol on the proliferation, apoptosis and telomerase ability of human A431 epidermoid carcinoma cells. Oncol. Lett. 2016, 11, 3015-3018. [CrossRef] [PubMed]

199. Zielińska-Przyjemska, M.; Kaczmarek, M.; Krajka-Kuźniak, V.; Łuczak, M.; Baer-Dubowska, W. The effect of resveratrol, its naturally occurring derivatives and tannic acid on the induction of cell cycle arrest and apoptosis in rat C6 and human T98G glioma cell lines. Toxicol. In Vitro 2017, 43, 69-75. [CrossRef] [PubMed]

200. Jordan, L.G.; Booth, B.W. HER2+ breast cancer cells undergo apoptosis upon exposure to tannic acid released from remodeled cross-linked collagen type I. J. Biomed. Mater. Res. A 2017. [CrossRef] [PubMed]

201. Zhang, J.; Cui, L.; Han, X.; Zhang, Y.; Zhang, X.; Chu, X.; Zhang, F.; Zhang, Y.; Chu, L. Protective effects of tannic acid on acute doxorubicin-induced cardiotoxicity: Involvement of suppression in oxidative stress, inflammation, and apoptosis. Biomed. Pharmacother. 2017, 93, 1253-1260. [CrossRef] [PubMed]

202. Shimozu, Y.; Kimura, Y.; Esumi, A.; Aoyama, H.; Kuroda, T.; Sakagami, H.; Hatano, T. Ellagitannins of Davidia involucrata L. structure of davicratinic acid a and effects of davidia tannins on drug-resistant bacteria and human oral squamous cell carcinomas. Molecules 2017, 22, 470. [CrossRef]

203. Fu, S.; Yang, Y.; Liu, D.; Luo, Y.; Ye, X.; Liu, Y.; Chen, X.; Wang, S.; Wu, H.; Wang, Y.; et al. Flavonoids and tannins from Smilax china L. rhizome induce apoptosis via mitochondrial pathway and MDM2-p53 signaling in human lung adenocarcinoma cells. Am. J. Chin. Med. 2017, 45, 369-384. [PubMed]

204. Darvin, P.; Joung, Y.H.; Kang, D.Y.; Sp, N.; Byun, H.J.; Hwang, T.S.; Sasidharakurup, H.; Lee, C.H.; Cho, K.H.; Park, K.D.; et al. Tannic acid inhibits EGFR/STAT1/3 and enhances p38/STAT1 signalling axis in breast cancer cells. J. Cell Mol. Med. 2017, 21, 720-734. [CrossRef] [PubMed]

205. Adaramoye, O.; Erguen, B.; Nitzsche, B.; Höpfner, M.; Jung, K.; Rabien, A. Punicalagin, a polyphenol from pomegranate fruit, induces growth inhibition and apoptosis in human PC-3 and LNCaP cells. Chem. Biol. Interact. 2017, 274, 100-106. [CrossRef] [PubMed] 
206. Pumiputavon, K.; Chaowasku, T.; Saenjum, C.; Osathanunkul, M.; Wungsintaweekul, B.; Chawansuntati, K.; Wipasa, J.; Lithanatudom, P. Cell cycle arrest and apoptosis induction by methanolic leaves extracts of four Annonaceae plants. BMC Complement. Altern. Med. 2017, 17, 294. [CrossRef] [PubMed]

207. Gali-Muhtasib, H.U.; Yamout, S.Z.; Sidani, M.M. Tannins protect against skin tumor promotion induced by ultraviolet-B radiation in hairless mice. Nutr. Cancer 2000, 37, 73-77. [CrossRef] [PubMed]

208. Tietbohl, L.A.C.; Oliveira, A.P.; Esteves, R.S.; Albuquerque, R.D.D.G.; Folly, D.; Machado, F.P.; Corrêa, A.L.; Santos, M.G.; Ruiz, A.L.G.; Rocha, L. Antiproliferative activity in tumor cell lines, antioxidant capacity and total phenolic, flavonoid and tannin contents of Myrciaria floribunda. An. Acad. Bras. Cienc. 2017, 89, 1111-1120. [CrossRef] [PubMed]

209. Vergara-Jimenez, M.; Almatrafi, M.M.; Fernandez, M.L. Bioactive components in Moringa Oleifera leaves protect against chronic disease. Antioxidants 2017, 6, 91. [CrossRef] [PubMed]

210. Singh, S.; Dubey, V.; Singh, D.K.; Fatima, K.; Ahmad, A.; Luqman, S. Antiproliferative and antimicrobial efficacy of the compounds isolated from the roots of Oenothera biennis L. J. Pharm. Pharmacol. 2017, 69, 1230-1243. [CrossRef] [PubMed]

211. Kumar, N.; Biswas, S.; Mathew, A.E.; Varghese, S.; Mathew, J.E.; Nandakumar, K.; Aranjani, J.M.; Lobo, R. Pro-apoptotic and cytotoxic effects of enriched fraction of Elytranthe parasitica (L.) Danser against HepG2 hepatocellular carcinoma. BMC Complement. Altern Med. 2016, 16, 420. [CrossRef] [PubMed]

212. Colomer, R.; Sarrats, A.; Lupu, R.; Puig, T. Natural polyphenols and their synthetic analogs as emerging anticancer agents. Curr. Drug Target 2017, 18, 147-159. [CrossRef] [PubMed]

213. Liu, Y.B.; Gao, X.; Deeb, D.; Pindolia, K.; Gautam, S.C. Role of telomerase in anticancer activity of pristimerin in prostate cancer cells. J. Exp. Ther. Oncol. 2017, 11, 41-49. [PubMed]

214. Moradzadeh, M.; Hosseini, A.; Erfanian, S.; Rezaei, H. Epigallocatechin-3-gallate promotes apoptosis in human breast cancer T47D cells through down-regulation of PI3K/AKT and telomerase. Pharmacol. Rep. 2017, 69, 924-928. [CrossRef] [PubMed]

215. Gurung, R.L.; Lim, S.N.; Low, G.K.; Hande, M.P. MST-312 alters telomere dynamics, gene expression profiles and growth in human breast cancer cells. J. Nutrigenet. Nutrigenom. 2014, 7, 283-298. [CrossRef] [PubMed]

216. Fatemi, A.; Safa, M.; Kazemi, A. MST-312 induces G2/M cell cycle arrest and apoptosis in APL cells through inhibition of telomerase activity and suppression of NF-kB pathway. Tumour Biol. 2015, 36, 8425-8437. [CrossRef] [PubMed]

217. Liu, L.; Zuo, J.; Wang, G. Epigallocatechin-3-gallate suppresses cell proliferation and promotes apoptosis in Ec9706 and Eca109 esophageal carcinoma cells. Oncol. Lett. 2017, 14, 4391-4395. [CrossRef] [PubMed]

218. Zhang, W.; Yang, P.; Gao, F.; Yang, J.; Yao, K. Effects of epigallocatechin gallate on the proliferation and apoptosis of the nasopharyngeal carcinoma cell line CNE2. Exp. Ther. Med. 2014, 8, 1783-1788. [CrossRef] [PubMed]

219. Gerhardt, D.; Bertola, G.; Dietrich, F.; Figueiró, F.; Zanotto-Filho, A.; Moreira Fonseca, J.C.; Morrone, F.B.; Barrios, C.H.; Battastini, A.M.; Salbego, C.G. Boldine induces cell cycle arrest and apoptosis in T24 human bladder cancer cell line via regulation of ERK, AKT, and GSK-3ß. Urol. Oncol. 2014, 32, 36.e1-36.e9. [CrossRef] [PubMed]

220. Gerhardt, D.; Horn, A.P.; Gaelzer, M.M.; Frozza, R.L.; Delgado-Cañedo, A.; Pelegrini, A.L.; Henriques, A.T.; Lenz, G.; Salbego, C. Boldine: A potential new antiproliferative drug against glioma cell lines. Invest. New Drugs 2009, 27, 517-525. [CrossRef] [PubMed]

221. Noureini, S.K.; Wink, M. Dose-dependent cytotoxic effects of boldine in HepG-2 cells-telomerase inhibition and apoptosis induction. Molecules 2015, 20, 3730-3743. [CrossRef] [PubMed]

222. Paydar, M.; Kamalidehghan, B.; Wong, Y.L.; Wong, W.F.; Looi, C.Y.; Mustafa, M.R. Evaluation of cytotoxic and chemotherapeutic properties of boldine in breast cancer using in vitro and in vivo models. Drug Des. Dev. Ther. 2014, 8, 719-733.

223. Imanshahidi, M.; Hosseinzadeh, H. Pharmacological and therapeutic effects of Berberis vulgaris and its active constituent, berberine. Phytother. Res. 2008, 22, 999-1012. [CrossRef] [PubMed]

224. Wu, H.L.; Hsu, C.Y.; Liu, W.H.; Yung, B.Y. Berberine-induced apoptosis of human leukemia HL-60 cells is associated with down-regulation of nucleophosmin/B23 and telomerase activity. Int. J. Cancer 1999, 81, 923-929. [CrossRef]

225. Naasani, I.; Seimiya, H.; Yamori, T.; Tsuruo, T. FJ5002: A potent telomerase inhibitor identified by exploiting the disease-oriented screening program with COMPARE analysis. Cancer Res. 1999, 59, 4004-4011. [PubMed] 
226. Zhang, W.J.; Ou, T.M.; Lu, Y.J.; Huang, Y.Y.; Wu, W.B.; Huang, Z.S.; Zhou, J.L.; Wong, K.Y.; Gu, L.Q. 9-Substituted berberine derivatives as G-quadruplex stabilizing ligands in telomeric DNA. Bioorg. Med. Chem. 2007, 15, 5493-5501. [CrossRef] [PubMed]

227. Ma, Y.; Ou, T.M.; Hou, J.Q.; Lu, Y.J.; Tan, J.H.; Gu, L.Q.; Huang, Z.S. 9-N-Substituted berberine derivatives: Stabilization of G-quadruplex DNA and down-regulation of oncogene c-myc. Bioorg. Med. Chem. 2008, 16, 7582-7591. [CrossRef] [PubMed]

228. Ma, Y.; Ou, T.M.; Tan, J.H.; Hou, J.Q.; Huang, S.L.; Gu, L.Q.; Huang, Z.S. Synthesis and evaluation of 9-O-substituted berberine derivatives containing aza-aromatic terminal group as highly selective telomeric G-quadruplex stabilizing ligands. Bioorg. Med. Chem. Lett. 2009, 19, 3414-3417. [CrossRef] [PubMed]

229. Cevatemre, B.; Erkısa, M.; Aztopal, N.; Karakas, D.; Alper, P.; Tsimplouli, C.; Sereti, E.; Dimas, K.; Armutak, E.I.I.; Gurevin, E.G.; et al. A promising natural product, pristimerin, results in cytotoxicity against breast cancer stem cells in vitro and xenografts in vivo through apoptosis and an incomplete autopaghy in breast cancer. Pharmacol. Res. 2017. [CrossRef]

230. Wu, C.C.; Chan, M.L.; Chen, W.Y.; Tsai, C.Y.; Chang, F.R.; Wu, Y.C. Pristimerin induces caspase-dependent apoptosis in MDA-MB-231 cells via direct effects on mitochondria. Mol. Cancer Ther. 2005, 4, 1277-1285. [CrossRef] [PubMed]

231. Yang, H.; Landis-Piwowar, K.R.; Lu, D.; Yuan, P.; Li, L.; Reddy, G.P.; Yuan, X.; Dou, Q.P. Pristimerin induces apoptosis by targeting the proteasome in prostate cancer cells. J. Cell. Biochem. 2008, 103, 234-244. [CrossRef] [PubMed]

232. Byun, J.Y.; Kim, M.J.; Eum, D.Y.; Yoon, C.H.; Seo, W.D.; Park, K.H.; Hyun, J.W.; Lee, Y.S.; Lee, J.S.; Yoon, M.Y.; et al. Reactive oxygen species-dependent activation of Bax and poly(ADP-ribose) polymerase-1 is required for mitochondrial cell death induced by triterpenoid pristimerin in human cervical cancer cells. Mol. Pharmacol. 2009, 76, 734-744. [CrossRef] [PubMed]

233. Tiedemann, R.E.; Schmidt, J.; Keats, J.J.; Shi, C.X.; Zhu, Y.X.; Palmer, S.E.; Mao, X.; Schimmer, A.D.; Stewart, A.K. Identification of a potent natural triterpenoid inhibitor of proteosome chymotrypsin-like activity and NF-kappaB with antimyeloma activity in vitro and in vivo. Blood 2009, 113, 4027-4037. [CrossRef] [PubMed]

234. Deeb, D.; Gao, X.; Liu, Y.; Pindolia, K.; Gautam, S.C. Inhibition of hTERT/telomerase contributes to the antitumor activity of pristimerin in pancreatic ductal adenocarcinoma cells. Oncol. Rep. 2015, 34, 518-524. [CrossRef] [PubMed]

235. Deeb, D.; Gao, X.; Liu, Y.; Varma, N.R.; Arbab, A.S.; Gautam, S.C. Inhibition of telomerase activity by oleanane triterpenoid CDDO-Me in pancreatic cancer cells is ROS-dependent. Molecules 2013, 18, 3250-3265. [CrossRef] [PubMed]

236. Yore, M.M.; Liby, K.T.; Honda, T.; Gribble, G.W.; Sporn, M.B. The synthetic triterpenoid 1-[2-cyano-3, 12-dioxooleana-1, 9-dien-28-oyl]imidazole blocks nuclear factor-kappaB activation through direct inhibition of IkappaB kinase beta. Mol. Cancer Ther. 2006, 5, 3232-3239. [CrossRef] [PubMed]

237. Liu, Y.; Gao, X.; Deeb, D.; Arbab, A.S.; Gautam, S.C. Telomerase reverse transcriptase (TERT) is a therapeutic target of oleanane triterpenoid CDDO-Me in prostate cancer. Molecules 2012, 17, 14795-14809. [CrossRef] [PubMed]

238. Deeb, D.; Gao, X.; Liu, Y.; Kim, S.H.; Pindolia, K.R.; Arbab, A.S.; Gautam, S.C. Inhibition of cell proliferation and induction of apoptosis by oleanane triterpenoid (CDDO-Me) in pancreatic cancer cells is associated with the suppression of hTERT gene expression and its telomerase activity. Biochem. Biophys. Res. Commun. 2012, 422, 561-567. [CrossRef] [PubMed]

239. Wang, X.; Chen, Y.; Han, Q.B.; Chan, C.Y.; Wang, H.; Liu, Z.; Cheng, C.H.; Yew, D.T.; Lin, M.C.; He, M.L.; et al. Proteomic identification of molecular targets of gambogic acid: Role of stathmin in hepatocellular carcinoma. Proteomics 2009, 9, 242-253. [CrossRef] [PubMed]

240. Zhao, T.; Wang, H.J.; Zhao, W.W.; Sun, Y.L.; Hu, L.K. Gambogic acid improves non-small cell lung cancer progression by inhibition of mTOR signaling pathway. Kaohsiung J. Med. Sci. 2017, 33, 543-549. [CrossRef] [PubMed]

241. Zhang, D.; Zou, Z.; Ren, W.; Qian, H.; Cheng, Q.; Ji, L.; Liu, B.; Liu, Q. Gambogic acid-loaded PEG-PCL nanoparticles act as an effective antitumor agent against gastric cancer. Pharm. Dev. Technol. 2017, 3, 1-8. [CrossRef] [PubMed] 
242. Pan, H.; Jansson, K.H.; Beshiri, M.L.; Yin, J.; Fang, L.; Agarwal, S.; Nguyen, H.; Corey, E.; Zhang, Y.; Liu, J.; et al. Gambogic acid inhibits thioredoxin activity and induces ROS-mediated cell death in castration-resistant prostate cancer. Oncotarget 2017, 8, 77181-77194. [CrossRef] [PubMed]

243. Li, Q.; Cheng, H.; Zhu, G.; Yang, L.; Zhou, A.; Wang, X.; Fang, N.; Xia, L.; Su, J.; Wang, M.; et al. Gambogenic acid inhibits proliferation of A549 cells through apoptosis-inducing and cell cycle arresting. Biol. Pharm. Bull. 2010, 33, 415-420. [CrossRef] [PubMed]

244. Fu, W.M.; Zhang, J.F.; Wang, H.; Tan, H.S.; Wang, W.M.; Chen, S.C.; Zhu, X.; Chan, T.M.; Tse, C.M.; Leung, K.S.; et al. Apoptosis induced by 1,3, 6, 7-tetrahydroxyxanthone in hepatocellular carcinoma and proteomic analysis. Apoptosis 2012, 17, 842-851. [CrossRef] [PubMed]

245. Guo, Q.L.; Lin, S.S.; You, Q.D.; Gu, H.Y.; Yu, J.; Zhao, L.; Qi, Q.; Liang, F.; Tan, Z.; Wang, X. Inhibition of human telomerase reverse transcriptase gene expression by gambogic acid in human hepatoma SMMC-7721 cells. Life Sci. 2006, 78, 1238-1245. [CrossRef] [PubMed]

246. Yu, J.; Guo, Q.L.; You, Q.D.; Zhao, L.; Gu, H.Y.; Yang, Y.; Zhang, H.W.; Tan, Z.; Wang, X. Gambogic acid-induced G2/M phase cell-cycle arrest via disturbing CDK7-mediated phosphorylation of CDC2/p34 in human gastric carcinoma BGC-823 cells. Carcinogenesis 2007, 28, 632-638. [CrossRef] [PubMed]

(C) 2017 by the authors. Licensee MDPI, Basel, Switzerland. This article is an open access article distributed under the terms and conditions of the Creative Commons Attribution (CC BY) license (http:/ / creativecommons.org/licenses/by/4.0/). 